\title{
Engineering the Solid Oxide Fuel Cell Through Infiltrating the Porous Electrodes
}

Bryan Jackson

Follow this and additional works at: https://researchrepository.wvu.edu/etd

\section{Recommended Citation}

Jackson, Bryan, "Engineering the Solid Oxide Fuel Cell Through Infiltrating the Porous Electrodes" (2018). Graduate Theses, Dissertations, and Problem Reports. 7192.

https://researchrepository.wvu.edu/etd/7192

This Thesis is protected by copyright and/or related rights. It has been brought to you by the The Research Repository @ WVU with permission from the rights-holder(s). You are free to use this Thesis in any way that is permitted by the copyright and related rights legislation that applies to your use. For other uses you must obtain permission from the rights-holder(s) directly, unless additional rights are indicated by a Creative Commons license in the record and/ or on the work itself. This Thesis has been accepted for inclusion in WVU Graduate Theses, Dissertations, and Problem Reports collection by an authorized administrator of The Research Repository @ WVU. For more information, please contact researchrepository@mail.wvu.edu. 


\title{
Engineering the Solid Oxide Fuel Cell Through Infiltrating the Porous Electrodes
}

\author{
Bryan Jackson
}

Thesis

Submitted to the College of Engineering and Mineral Resources at West Virginia University

in partial fulfillment of the requirements for the degree of Masters of Science in

Mechanical Engineering

Committee members:

Xueyan Song, Ph.D, Chair

Yun Chen, Ph.D

Jacky Prucz, Ph.D

Hailin Li, Ph.D

Department of Mechanical and Aerospace Engineering West Virginia University Morgantown, West Virginia

July 2018

Keywords: Solid Oxide Fuel Cell

Copyright 2018 Bryan Jackson 


\section{Abstract \\ Engineering the Solid Oxide Fuel Cell Through Infiltrating the Porous Electrodes}

\section{Bryan Jackson}

Solid oxide fuel cells (SOFCs) are promising alternatives in energy conversion to produce energy electrochemically, with high energy conversion efficiency, instead of using the conventional combustion process. However, the current state of the art SOFCs need to be further improved in terms of performance and durability to become more economically competitive. In particular, improvements need to be made to increase the cell power density and lower the reaction resistance of porous electrode at operation temperature of $650-800^{\circ} \mathrm{C}$. Appropriate infiltration of nano materials into the porous composite electrode could lower the resistance and mitigate the electrode degradation. In this work numerous techniques are investigated for the infiltration of the conductors and elecrocatalyst into the porous anode and cathode, respectively. Nano-scaled oxide was introduced to porous $\mathrm{Ni} / \mathrm{YSZ}$ anode with the aim of introducing the additional reaction pathway and increasing the coking resistance when fueled with hydrocarbons. Both the nano-scaled oxide and metallic particles were introduced to the porous LSM/YSZ cathode with the aim of lowering the resistance of oxygen reduction reaction. Impact of the infiltrate on the microstructure of the electrodes is evaluated through the combination of scanning electron microscopy, transmission electron microscopy, and energy dispersive x-ray spectroscopy. Electrochemical impedance spectroscopy (EIS) is used to study the effects of infiltrates on the change of resistance of SOFCs. Some appropriate infiltrate materials and suitable infiltration processes are thus determined for porous electrodes of SOFCs. 


\section{Acknowledgements}

I would like to thank the Benjamin M. Statler College of Engineering and Mineral Resources

Department of Mechanical and Aerospace Engineering along with my advising and examining committee members including Dr. Jacky Prucz, Dr. Hailin Li, Dr. Yun Chen, and my committee chair Dr. Xueyan Song.

We acknowledge the use of the WVU Shared Research Facilities 


\section{Table of Contents}

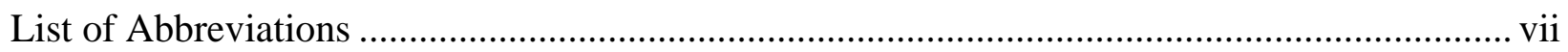

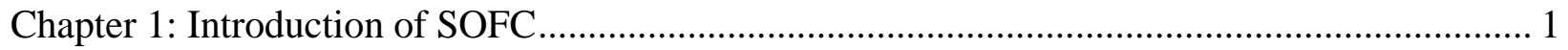

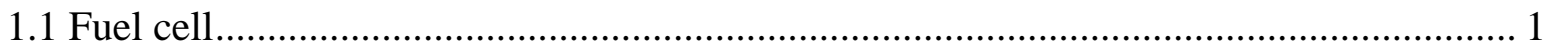

1.2 History of fuel cell development..................................................................... 2

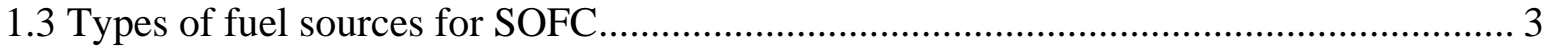

1.4 SOFC advantages, current SOFC applications, and its difficulty/challenges for

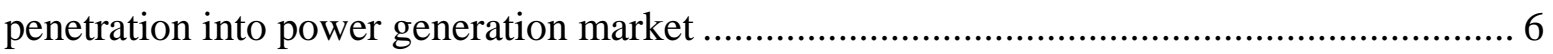

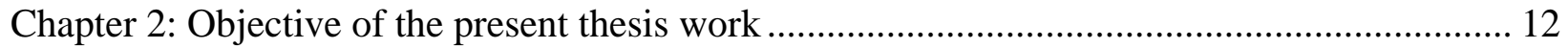

Chapter 3: Ni/YSZ anode and anode infiltration ........................................................... 14

3.1 State of the art Ni/YSZ anode and its challenges for natural gas utilization ................. 14

3.1 Chemical solution based anode infiltration of Ni/YSZ anode ................................... 20

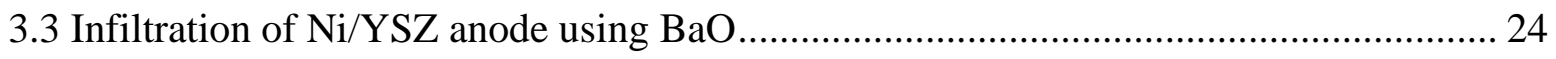

Chapter 4: LSM/YSZ cathode and cathode infiltration ........................................................ 35

4.1 State of the art LSM/YSZ cathode design advantages and disadvantages .................. 35

4.2 Effect of infiltration on LSM/YSZ cathode ........................................................ 40

4.2.1 Infiltration of LSM/YSZ cathode using silver nanoparticles .............................. 40

4.2.2 Infiltration of LSM/YSZ cathode using lanthanum nickelates ............................ 46

4.2.3 Infiltration of LSM/YSZ cathode using manganese oxide ................................ 56

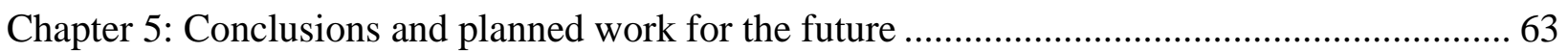




\section{Table of Figures}

Figure 1.1: Schematic of Solid Oxide Fuel Cell .......................................................... 2

Figure 1.2: Fuel cell schematic for the Grove's Fuel Cell ......................................... 3

Figure 1.2: Comparison of electrical efficiency and power plant size between various energy production methods ................................................................................ 7

Figure 1.3: Losses in off-site vs decentralized SOFC power generation...................... 8

Figure 3.1: Effectiveness of a pure metal (a) versus a mixing an electronic and ionic conductor (b) in the triple phase boundary ....

Figure 3.2: (left) Cross section image of failure at the active region due to carbon deposition (right) Surface view carbon deposition on fuel cell .....

Figure 3.3: Schematic of porous Ni/YSZ anode and infiltration of nano materials on the internal surface of $\mathrm{Ni} / \mathrm{YSZ}$ Cermet Anode

Figure 3.4: Surface of Ni/YSZ anode before infiltration (left) surface of Ni/YSZ anode with optimal barium oxide concentration (right)..... 30

Figure 3.5: Light microscopy images of dendrites present on the surface of a BaO-5-1

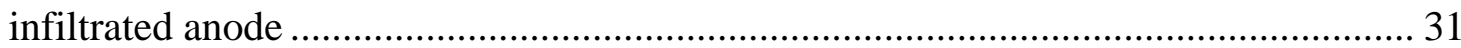

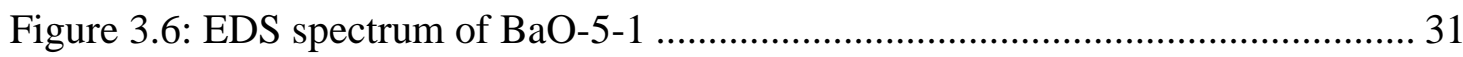

Figure 3.7: TEM of barium oxide infiltration into active layer (left) and corresponding

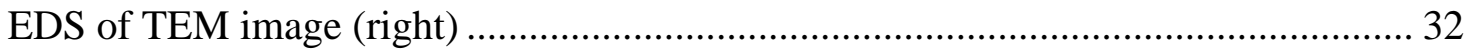

Figure 4.1: Four point measurement schematic .................................................. 40

Figure 4.2: UV spectrum of gold nanoparticle standard (left) with reference spectrum of gold nanoparticles (right)

Figure 4.3: Experimental UV silver nanoparticle spectrum compared to reference spectrum.

Figure 4.4 TEM confirming presence of a contaminant in Ag-nanoparticle Solution . 44

Figure 4.5: Polarization resistance of Ag-nanoparticles compared to baseline ran at 600 and $650 \mathrm{C}$ (left) and $700 \mathrm{C}$ (right)

Figure 4.6: Polarization resistance comparison of silver nanoparticle infiltrated LSM/YSZ cell with respect to the baseline LSM/YSZ cell.

Figure 4.7: Series (left) and total (right) resistance at 12 hours of Ag-nanoparticle infiltrated LSM/YSZ cell with respect to the baseline LSM/YSZ cell ....................... 46

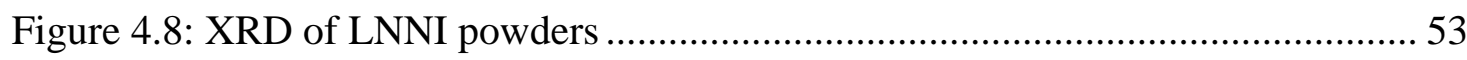


Figure 4.9: Polarization Resistance of Lanthanum Nickelate infiltrated cells in comparison to baseline with temperature ran at 600, $650 \mathrm{C}$ (left) and 700, $750 \mathrm{C}$ (right)

Figure 4.10: Polarization resistance comparison of lanthanum nickelate infiltrated $\mathrm{LSM} / \mathrm{YSZ}$ cell with respect to the baseline LSM/YSZ cell.....

Figure 4.11: Series (left) and total (right) resistance comparison of lanthanum nickelate infiltrated LSM/YSZ cell with respect to the baseline LSM/YSZ cell.....

Figure 4.12: Polarization resistance comparison of manganese oxide with respect to the baseline ran at 600, $650 \mathrm{C}$ (left) and 700, $750 \mathrm{C}$ (right)

Figure 4.13: Polarization resistance comparison of manganese oxide infiltrated $\mathrm{LSM} / \mathrm{YSZ}$ cell with respect to the baseline LSM/YSZ cell...................................... 58

Figure 4.14: Series (left) and total (right) resistance comparison of manganese oxide infiltrated LSM/YSZ cell with respect to the baseline LSM/YSZ cell. 58 


\section{List of Abbreviations}

Deionized Water. .DI Water

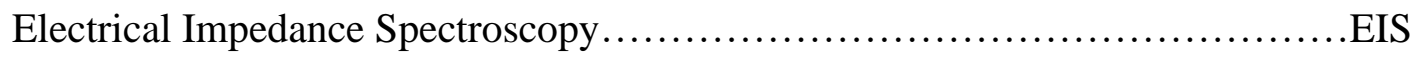

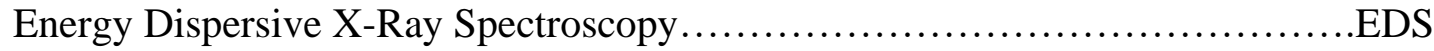

Lanthanum Nickel Oxide................................................

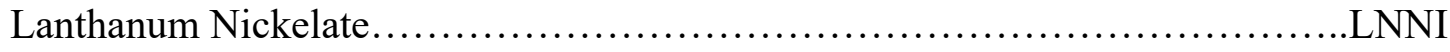

Molten Carbonate Fuel Cell...................................................FC

Nickel/Yittria Stabilized Zirconium........................................

Open Circuit Voltage............................................................

Oxygen Reduction Reaction..............................................

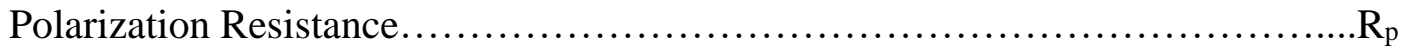

Proton-Exchange Membrane Fuel Cell.....................................PEMFC

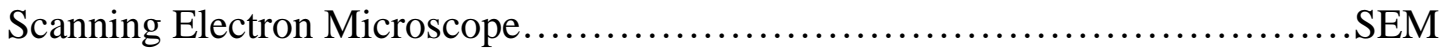

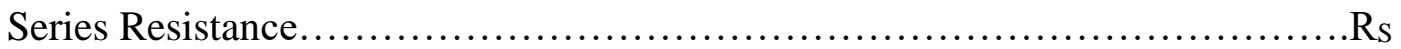

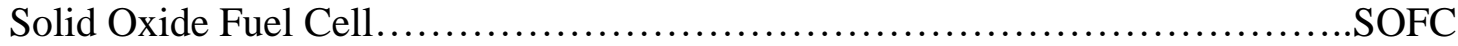

Temperature Programmed Oxidation..........................................TPO

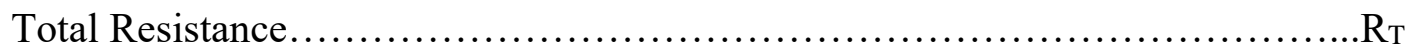

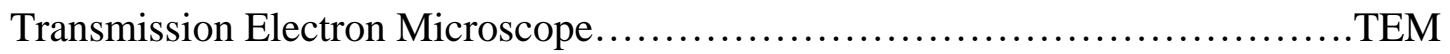

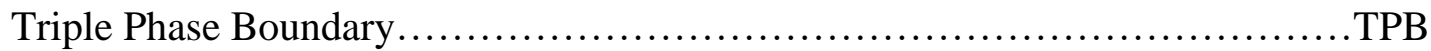

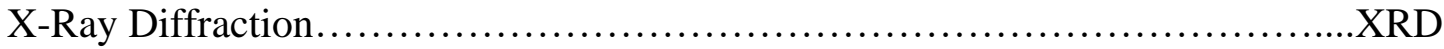

Yittria Stabilized Zirconia.................................................YSZ 


\section{Chapter 1: Introduction of SOFC}

\subsection{Fuel cell}

Fuel cell technology is used to generate energy electrochemically thus eliminating the efficiency cap placed on the system by the Carnot cycle that exists in conventional generators. ${ }^{1}$ A major problem facing the world today is the low efficiency obtained through power generation systems. It is currently estimated that around $70 \%$ of this available energy that is generated from the traditional centralized power stations is wasted. These stations, having high $\mathrm{CO}_{2}$ emissions and running costs generally operate at between 30 and $40 \%$ efficiency. $^{2}$

Solid oxide fuel cell (SOFC) systems offer a clean, low-pollution technology to generate electricity at high efficiencies. ${ }^{3}$ Efficiencies of SOFC systems are around $50 \%$ in comparison to the $30-40 \%$ typically yielded from combustion processes. ${ }^{4}$ If the SOFC systems are lumped into a combined heat and power system the efficiencies can reach as high as $90 \%$. This is due to such systems utilizing heat that would normally be wasted from the SOFCs to control power, heat, cooling, and humidity.

SOFC technology utilizes a ceramic electrolyte, operating at high temperatures from 6001000 C. At these high temperatures it is possible to use fuels such as natural gas, coal, biofuels, as well as hydrogen. This is due to the ability of the heat produced by the fuel cell to reform these fuels into carbon monoxide and hydrogen. ${ }^{5}$

SOFCs are fuel cell systems that utilize the electrochemical reaction between oxygen anions and a fuel source that consists usually of carbon monoxide and hydrogen, along with small amounts of elemental carbon to produce electricity. ${ }^{5}$ At the anode the fuel reacts with oxygen anions that were reduced at the cathode to produce electrons. These electrons travel 
through a circuit from the anode to the cathode to reduce oxygen being fed to the cathode usually as air. SOFCs contain a dense solid oxide electrolyte ceramic such as yittria stabilized zirconia (YSZ) which can conduct oxygen ions at high temperatures but is dense enough to prevent electron conduction. ${ }^{5}$ The electrochemical half reactions for the fuel cell is given for the oxidation at the anode by equations (1) and (2), as well as for the oxygen reduction at the cathode side in equation 3. A schematic of such a system is shown in Figure 1.1.

$$
\begin{aligned}
& \mathrm{H}_{2}+\mathrm{O}^{2-}-2 e \rightarrow \mathrm{H}_{2} \mathrm{O} \\
& \mathrm{CO}+\mathrm{O}^{2-}-2 e \rightarrow \mathrm{CO}_{2} \\
& \mathrm{O}+2 e \rightarrow \mathrm{O}^{2-}
\end{aligned}
$$

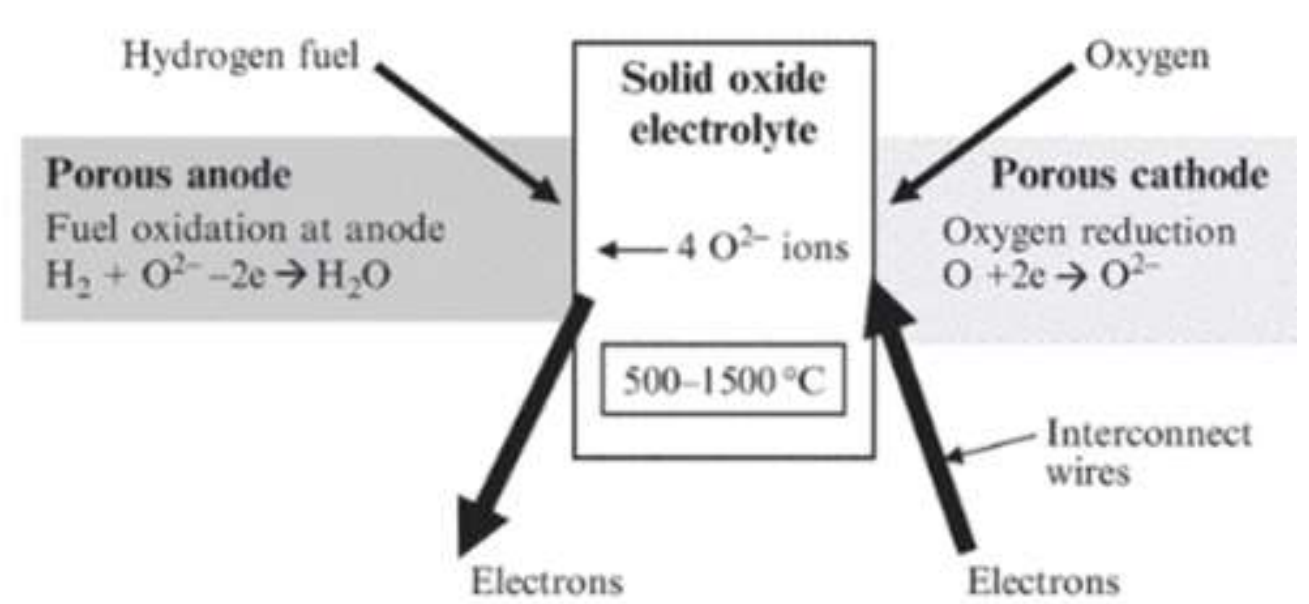

Figure 1.1: Schematic of Solid Oxide Fuel Cell ${ }^{5}$

\subsection{History of fuel cell development}

The first fuel cell was built and tested by Sir William Grove in 1839 in what he called a voltaic gas battery. ${ }^{6}$ A schematic of his type of design is illustrated in Figure 1.2. This was a cell with a platinum electrode in a solution of sulfuric acid. The cell ran off pure hydrogen as the fuel and oxygen as the oxidant. 


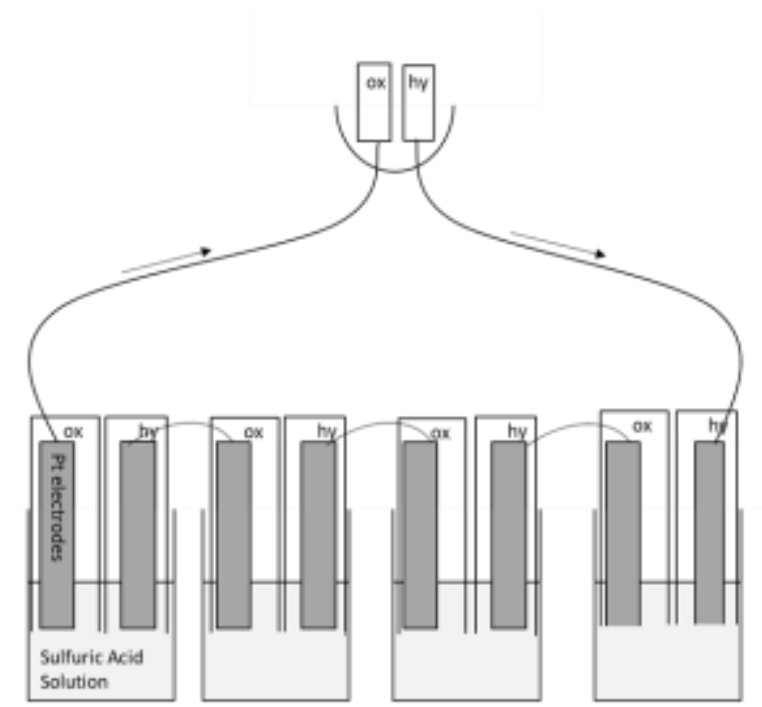

Figure 1.2: Fuel cell schematic for the Grove's Fuel Cell

The solid oxide fuel cell concept began, with the invention of the Nernst lamp by Walther Nernst in $1897 .^{7,8}$ This lamp used a thin rod that consisted of zirconium oxide with $15 \%$ yttrium oxide. It succeeded in having a higher efficiency than the carbon filament lamp but had problems such as having a long start-up time and not being conductive at room temperature. To make the lamp conductive a separate heater was required to heat up the rod. In 1943 after Nernst's death, Carl Wagner found that the oxygen ion conduction in the Nernst lamps were due to oxygen vacancies. ${ }^{7}$ Though the Nernst lamp has been replaced by the incandescent bulb the material design of a yittrium zirconium mixture is used in SOFCs as an oxygen ion conducting electrolyte.

\subsection{Types of fuel sources for SOFC}

A major advantage to the use of SOFC technology is its ability to reform fuels such as, natural gas, biofuels, and coal for a fuel source due to its high operating temperature and high tolerance to carbon monoxide. ${ }^{9}$ Natural gas is a much researched fuel source to be used in SOFCs. This is due to there already existing a supply infrastructure in place for natural gas. Hydrogen is an energy carrier as it does not exist freely in nature but must be produced. ${ }^{10}$ 
Hydrogen is often produced in these systems by the reforming of fossil fuels. Steam reforming follows the following reaction given in equation $4 .^{5}$

$$
\mathrm{CH}_{4}+\mathrm{H}_{2} \mathrm{O} \rightarrow \mathrm{CO}+3 \mathrm{H}_{2}
$$

Steam reforming of natural gas is currently the most economical way to produce Hydrogen. ${ }^{10}$ Due to high operating temperatures (SOFC) have the ability to carry out this reforming process with natural gas. At temperatures as low as $600 \mathrm{C}^{11}$ natural gas can be reformed with water to produce a fuel rich in $\mathrm{H}_{2}$ and $\mathrm{CO}$. When this fuel reacts with an oxygen anion that is reduced at the cathode side $\mathrm{H}_{2} \mathrm{O}$ and $\mathrm{CO}_{2}$ are formed as products to the reaction.

Prior to reforming of the natural gas it consists of a mixture of hydrocarbon gases. This mixture consists primarily of methane but can also include such hydrocarbons as ethane, propane, butane, and pentane. After the natural gas is refined the fuel consists almost entirely of methane $\left(\mathrm{CH}_{4}\right){ }^{11}$

A disadvantage in the use of natural gas is that it can contain sulfur either naturally ${ }^{12}$ or as an odorant for safety purposes. ${ }^{11}$ Without sulfur natural gas cannot be detected by human senses. The natural gas used by consumers is not harmful to the body but can cause asphyxiation if it displaces a significant amount of oxygen in breathing. Due to its toxicity odorants are typically added to natural gas. One type of odorant that is added is sulfur. This type is a mercaptan which means it will have a smell similar to rotten eggs. ${ }^{11}$ This addition of sulfur can potentially cause poisoning in the SOFC anode.

Fuels of higher hydrocarbons than methane are also sources of fuel in SOFC applications. ${ }^{1,13,14}$ Kerosene is a fuel that is commonly used in Japan for SOFC applications in homes. ${ }^{1}$ In the area of butane fueled solid oxide fuel cells Sengodan showed an A-site layered 
double perovskite manganese oxide of the form $\mathrm{PrBaMn} 2 \mathrm{O}_{5+\delta}$ had good redox, coking, and sulfur tolerance, as well as having good electrical conductivity. ${ }^{13}$ This material obtained power densities of 1.7 and $1.3 \mathrm{~W} \mathrm{~cm}^{-2}$ at $850 \mathrm{C}$ using humidified hydrogen and propane as the fuels respectively. Shin demonstrated that doped $\mathrm{CeO}_{2}-\mathrm{LaFeO}_{3}$ composite oxide could be used as an anode for direct hydrocarbon fuels. ${ }^{14}$ Shin's team demonstrated a power density of greater than $1.0 \mathrm{~W} \mathrm{~cm}^{-2}$ in fuels consisting of $\mathrm{C}_{3} \mathrm{H}_{10}$ and $\mathrm{C}_{4} \mathrm{H}_{10}$ with the power densities rising as the hydrocarbon rose, meaning that the material system did better with higher hydrocarbon fuels than it did with methane or $\mathrm{H}_{2}$ fuel sources. This was attributed to decreased IR loss and over potential of the anode. It was also demonstrated through Raman analysis that no coking was present after a long-duration test that utilized $\mathrm{C}_{3} \mathrm{H}_{8}$ and $\mathrm{CH}_{4}$ as the fuels.

Biogas is a type of renewable fuel source that has a potential in SOFC applications. ${ }^{1,15,16}$ Biogas can ensure a use for low-quality biogas that is generally wasted such as that from vegetable matter and landfill gas. Use of this type of biogas has been demonstrated in SOFC applications though it commonly has a problem with sulfur poisoning. ${ }^{1}$ SOFC applications that utilized biogas fuel sources in combined heat and power system was shown to be competitive with grid costs by Trendewicz. ${ }^{15}$ A disadvantage to this type of biogas application involves the necessity of using an anaerobic digester so it may not be economical on a small scale. It is also possible to use biogas in what is called a flame fuel cell. ${ }^{16}$ This kind of system uses the flame as both the reformer and the heater. The advantages includes less catalyst requirements and less thermal management requirements. This also aids in the long start-up time of traditional SOFCs in allowing for rapid start-up of the flame fuel cell. The residual gases are burned in this type of system for the total transformation of hydrogen and carbon monoxide. 
From a cost analysis perspective in biogas systems it should be noted that pretreatment should involve both the water and $\mathrm{H}_{2} \mathrm{~S}$ being removed. ${ }^{15}$ Although water is normally used to reform gases in SOFC systems, in biogas systems water is a contaminant because it condenses in the pipeline to react with the $\mathrm{H}_{2} \mathrm{~S}$ and becomes highly corrosive. Siloxanes would also need removed as they are added at the facilities as cleaning agents but are damaging to fuel cell stacks. This is because the silica can fill the pores in the anode and stop the reactant gas transport.

Coal has also been studied as a potential fuel source for SOFC operation. ${ }^{1,17,18}$ Coal syngas mainly consists of $\mathrm{CO} \cdot{ }^{17}$ It does have disadvantages, however due to various impurities that can be present in the fuel. Though coal syngas can be used to operate an SOFC the sulfur must be removed at least in part from the gas in order to prevent poisoning of the anode and loss of performance. ${ }^{1}$ It was showed by Chen that another type of impurity, phosphine, in coal syngas can be harmful to a SOFC. He studied the influence phosphine has on an anode of a SOFC system for both hydrogen and syngas fuels in which phosphine was added. ${ }^{18}$ The degradation of both the $\mathrm{Ni}$ anode and the YSZ structure were more susceptible to phosphine degradation when exposed to syngas with phosphine rather than hydrogen with phosphine. It was also found that the syngas phosphine added fuel caused an $\mathrm{YPO}_{4}$ phase in the TPB, whereas the $\mathrm{YPO}_{4}$ phase was non-existent in the hydrogen with phosphine added fuel.

\subsection{SOFC advantages, current SOFC applications, and its difficulty/challenges for penetration into power generation market}

Solid oxide fuel cells have higher efficiencies than that of the traditional power generation methods. Figure 1.2 shows the electrical efficiency of power generation methods versus the generation capacity of that method within a power plant. It is seen that at the SOFC systems are higher than all the systems except for the direct carbon fuel cells. The efficiency of 
the fuel cells can also be raised by hybridizing them with other power generation systems such as turbines. ${ }^{19}$

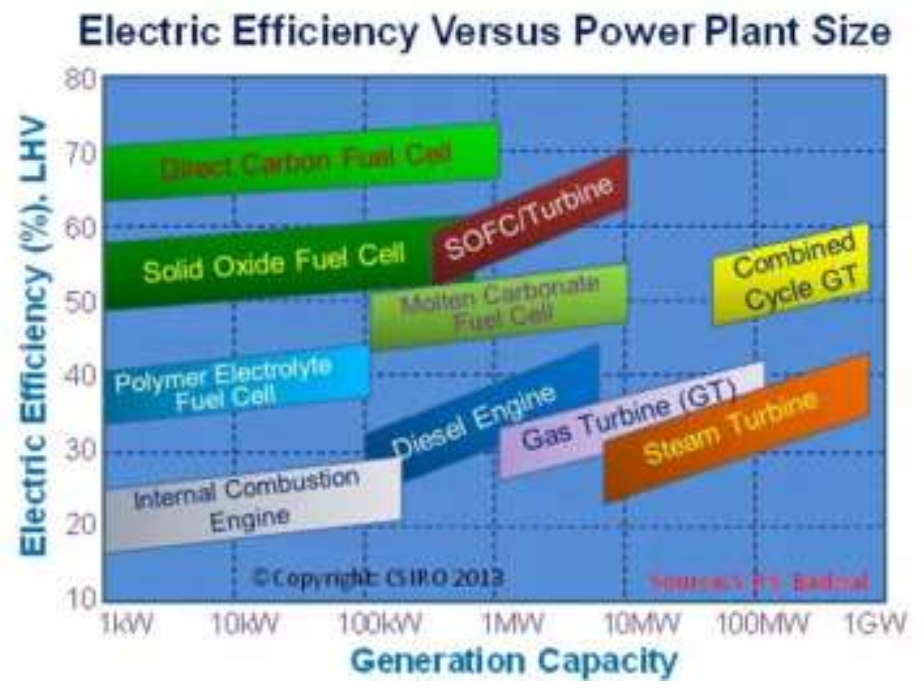

Figure 1.2: Comparison of electrical efficiency and power plant size between various energy production methods ${ }^{19}$

With buildings consuming around $40 \%$ of the energy available for cooling, heat, and power; one possible move is to switch from obtaining the majority of energy from the conventional power generation systems to obtaining energy from clean onsite power generation technology that operates at high efficiency. ${ }^{4}$ As the system would need to operate at high enough efficiencies to justify the capital costs of the systems associated with them, the best way to do this may be with cogeneration and trigeneration technologies that incorporate SOFC systems as the primary power generation system. Figure 1.3 illustrates the difference between the conventional central power generation process and the decentralized process that would be available in on-site SOFC usage with respect to energy losses. 


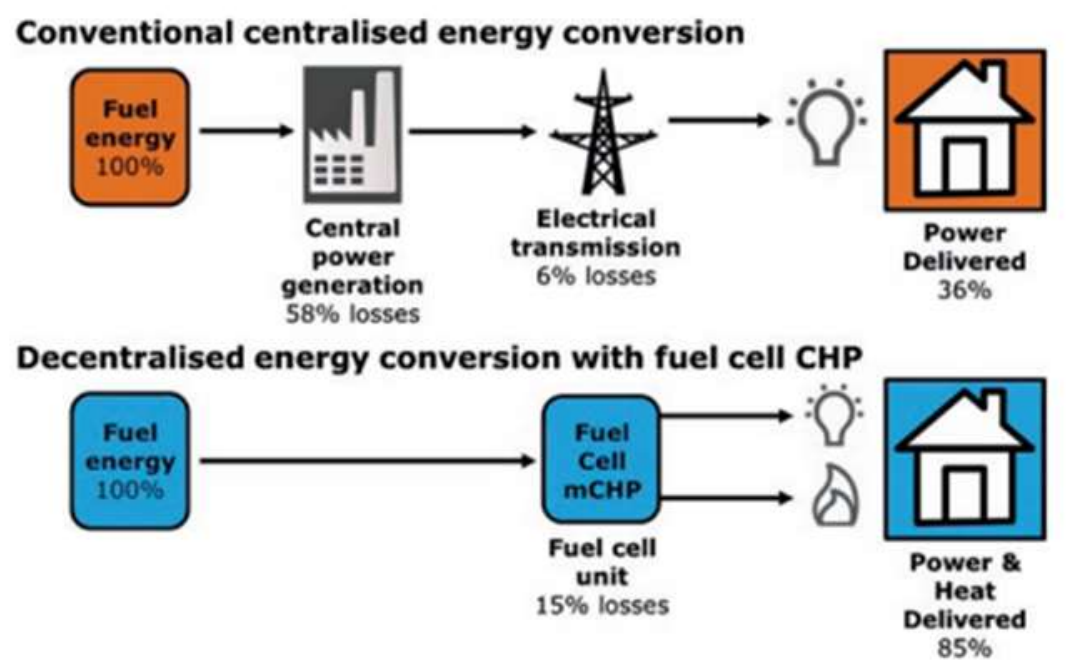

Figure 1.3: Losses in off-site vs decentralized SOFC power generation ${ }^{20}$

Waste heat can easily be recovered. In industry it is usually recovered as superheated steam such as in gas turbines. Heat is easy to store in that heat can easily be stored by methods such as storage in a hot water tank. The waste heat has been utilized in many areas in SOFC systems with some examples including heating for buildings, cooling for buildings, hybridization with turbines, water desalination, and powering thermoelectric generators. ${ }^{2,21,22,23,24}$

The lack of advancement of SOFC systems in the current market includes high capital cost due to not currently being mass produced, energy loss during start up and cool down, lower power density and high degradation rates leading to higher lifetime price, and limited material selection available due to the high temperature operation associated with such systems. Fuel cells typically have to be operated continually to account for the energy loss problem as well as possible failure due to thermal cycling. The degradation of the systems also leads to needing an increased fuel input. An example of system degradation is seen in a study done by Elmer. His study utilized a system that had a theoretical operational lifetime of 15 years with a needed stack replacement every 5 years. Due to problems such as unexpected shut-offs of the fuel cell, stack replacement was needed at earlier intervals. The specific system also had a beginning efficiency 
of $60 \%$ that was seen to degrade by $6 \%$ after 4000 hours. $^{2}$ More durable systems, especially the high performance and durable electrodes that experience less degradation or cheaper systems are needed for the SOFC to successfully infiltrate the power generation market. 


\footnotetext{
${ }^{1}$ Zhao, Li. Brouwer, Jacob. Liu, Jiew. James, Sean. Siegler, John. Kansal, Aman. Peterson, Eric. Fuel Cells for Data Centers: Power Generation Inches From the Server. FCDC- TechReport. February, 2016. Web. July 23, 2018. https://www.microsoft.com/en-us/research/wp-content/uploads/2016/02/FCDC-TechReport.pdf
}

${ }^{2}$ Elmer, T., Worall, M., Wu, S., \& Riffat, S. (2016). Assessment of a novel solid oxide fuel cell tri-generation system for building applications. Energy Conversion and Management, 124, 29-41.

${ }^{3}$ Singhal, S. (2002). Solid oxide fuel cells for stationary, mobile, and military applications. Solid State Ionics, 152, 405-410. doi:10.1016/S0167-2738(02)00349-1

${ }^{4}$ Small and Micro Combined Heat and Power (CHP) Systems: Advanced Design, Performance, Materials and

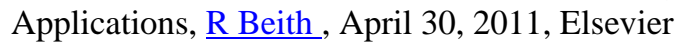

${ }^{5}$ In Kendall, K., \& In Kendall, M. (2016). High-temperature solid oxide fuel cells for the 21 st century:

Fundamentals, design and applications.

${ }^{6}$ Milewski, J. (2011). Advanced methods of solid oxide fuel cell modeling (Green energy and technology). London: Springer.

${ }^{7}$ Irvine, J., \& Connor, P. (2013). Solid oxide fuels cells : Facts and figures : Past, present and future perspectives for SOFC technologies(Green energy and technology). London: Springer.

${ }^{8}$ Blomen, L.J.M.J., Mugerwa, M.N., (1993). Fuel Cell Systems. Springer. pg 23

${ }^{9}$ In Kendall, K., \& In Kendall, M. (2016). High-temperature solid oxide fuel cells for the 21 st century:

Fundamentals, design and applications.

${ }^{10}$ Hoffmann, P. (2012). Tomorrow's energy: Hydrogen, fuel cells, and the prospects for a cleaner planet. Cambridge, Mass: MIT Press.

${ }^{11}$ Speight, J. G. (2007). Natural gas: A basic handbook. Houston, Tex: Gulf Pub. Co.

${ }^{12}$ Natgas. Processing Natural Gas. NaturalGas.org. September 25, 2013. Web. July 23, 2018. http://naturalgas.org/naturalgas/processing-ng/

${ }^{13}$ Sengodan, S., Choi, S., Jun, A., Shin, T. H., Ju, Y. W., Jeong, H. Y., Shin, J., ... Kim, G. (January 01, 2015). Layered oxygen-deficient double perovskite as an efficient and stable anode for direct hydrocarbon solid oxide fuel cells. Nature Materials, 14, 2, 205-9.

${ }^{14}$ Shin, T. H., Ida, S., \& Ishihara, T. (January 01, 2011). Doped CeO2-LaFeO3 composite oxide as an active anode for direct hydrocarbon-type solid oxide fuel cells. Journal of the American Chemical Society, 133, 48, 19399-407.

15 Trendewicz, A., \& Braun, R. (2013). Techno-economic analysis of solid oxide fuel cell-based combined heat and power systems for biogas utilization at wastewater treatment facilities. Journal of Power Sources, 233, 380-393. doi:10.1016/j.jpowsour.2013.01.017

${ }^{16}$ Zeng, H., Wang, Y., Shi, Y., \& Cai, N. (2017). Biogas-fueled flame fuel cell for micro-combined heat and power system. Energy Conversion and Management, 148, 701-707. doi:10.1016/j.enconman.2017.06.039

${ }^{17}$ Xiao, J., Xie, Y., Liu, J., \& Liu, M. (December 05, 2014). Deactivation of nickel-based anode in solid oxide fuel cells operated on carbon-containing fuels. Journal of Power Sources, 268, 508-516. 
${ }^{18}$ Chen, Y., Chen, S., Hackett, G., Finklea, H., Zondlo, J., Celik, I., Song, X., ... Gerdes, K. (March 01, 2013). Microstructure degradation of YSZ in Ni/YSZ anodes of SOFC operated in phosphine-containing fuels. Solid State Ionics, 234, 16, 25-32.

${ }^{19}$ Solid Oxide Fuel Cell Technology. CSIROpedia. Web. July 10, 2018. https://csiropedia.csiro.au/ceramic-fuelcells/

${ }^{20}$ A Novel SOFC Tri-generation System for Building Applications, Theo Elmer , November 19, 2016, Springer ${ }^{21}$ Chan, S., Ho, H., \& Tian, Y. (2002). Modelling of simple hybrid solid oxide fuel cell and gas turbine power plant. Journal of Power Sources, 109(1), 111-120. doi:10.1016/S0378-7753(02)00051-4

${ }^{22}$ Arsalis, A. (January 01, 2008). Thermoeconomic modeling and parametric study of hybrid SOFC-gas turbinesteam turbine power plants ranging from 1.5 to 10 MWe. Journal of Power Sources, 181, 2, 313-326.

${ }^{23}$ Meratizaman, M., Monadizadeh, S., \& Amidpour, M. (2014). Introduction of an efficient small-scale freshwaterpower generation cycle (SOFC-GT-MED), simulation, parametric study and economic assessment. Desalination, 351, 43-58. doi:10.1016/j.desal.2014.07.023

${ }^{24}$ Wei, T., Huang, Y.-H., Zhang, Q., Yuan, L.-X., Yang, J.-Y., Sun, Y.-M., Hu, X.-L., ... Goodenough, J. B. (April 24, 2012). Thermoelectric solid-oxide fuel cells with extra power conversion from waste heat. Chemistry of Materials, 24, 8, 1401-1403. 


\section{Chapter 2: Objective of the present thesis work}

The current state of the art SOFCs need to be further improved in terms of performance and durability to become more economically competitive. In particular, improvements need to be made to increase the cell power density and lower the reaction resistance of porous electrode at operation temperature of $650-800^{\circ} \mathrm{C}$. Appropriate infiltration of nano materials into the porous composite electrode could lower the resistance and mitigate the electrode degradation. In this work numerous techniques are investigated for the infiltration of the conductors and elecrocatalyst into the porous anode and cathode, respectively.

\section{Objective for infiltration into porous Ni/YSZ anode}

This experiment aims to discover an appropriate infiltrate to be used in the Ni/YSZ anode. The infiltrate material was selected to possibly mitigate carbon deposition as well as increase cell performance. Barium oxide was ultimately used due to the possibilities this material could mitigate the effects of carbon as well as cause reactions with $\mathrm{Zr}$ in the YSZ to form a $\mathrm{BaZrO}_{3}$ protonic conductor.

Once the material to be infiltrated is decided the experiment aims to investigate an appropriate technique for infiltration into the cell. This includes parameters such as the calcination temperature after infiltration, the appropriate chemical to put into the solution as a surfactant or chelating agent, as well as the concentration of the dissolved species in Deionized (DI) water. 
Scanning electron microscopy (SEM) and energy dispersive x-ray spectroscopy (EDS) analysis is used to verify the effectiveness of the procedure to obtain an even distribution of infiltrate particles of the correct chemistry on the surface of the cell. TEM and EDS analysis is used to verify the infiltration of the target chemistry into the active layer of the cell.

\section{Objective for infiltration into porous LSM/YSZ cathode}

The experiment performed on the LSM/YSZ cathode of the cell sought to improve the current state of the art design by investigating suitable infiltrates that could increase cell performance. These infiltrates should be able to lower the cell resistance throughout the temperature range and increase power density. Ionic conductive infiltrate materials were studied due to their ability to possibly increase the triple phase boundary (TPB).

This experiment focused on the infiltrate materials of the $\mathrm{LaNiO}_{3}$ form of lanthanum nickelates, silver nanoparticles, and manganese oxides. The aim of the experiment was to lower the polarization, series, and total resistances throughout the experimental temperature range of 600-750 C. 


\section{Chapter 3: Ni/YSZ anode and anode infiltration}

\subsection{State of the art Ni/YSZ anode and its challenges for natural gas utilization}

\section{$\underline{\mathrm{Ni} / \mathrm{YSZ} \text { anode }}$}

SOFC anodes typically meet at the TPB region. ${ }^{1}$ This is the region where the gas phase meets with the phases that carry the cations from the electrolyte and carry electrons to the circuit. A schematic of this is shown in Figure 3.1. In the metal based anode (a) the TPB region is limited to the electrolyte/electrode interface. Performance of the cell can be raised by extending the triple phase boundary by mixing an electronic and ionic conductor together (b). The regions (1) and (2) illustrate that if the TPB zones are not connected to both the ionic and electronic paths then they are not effective. ${ }^{2}$

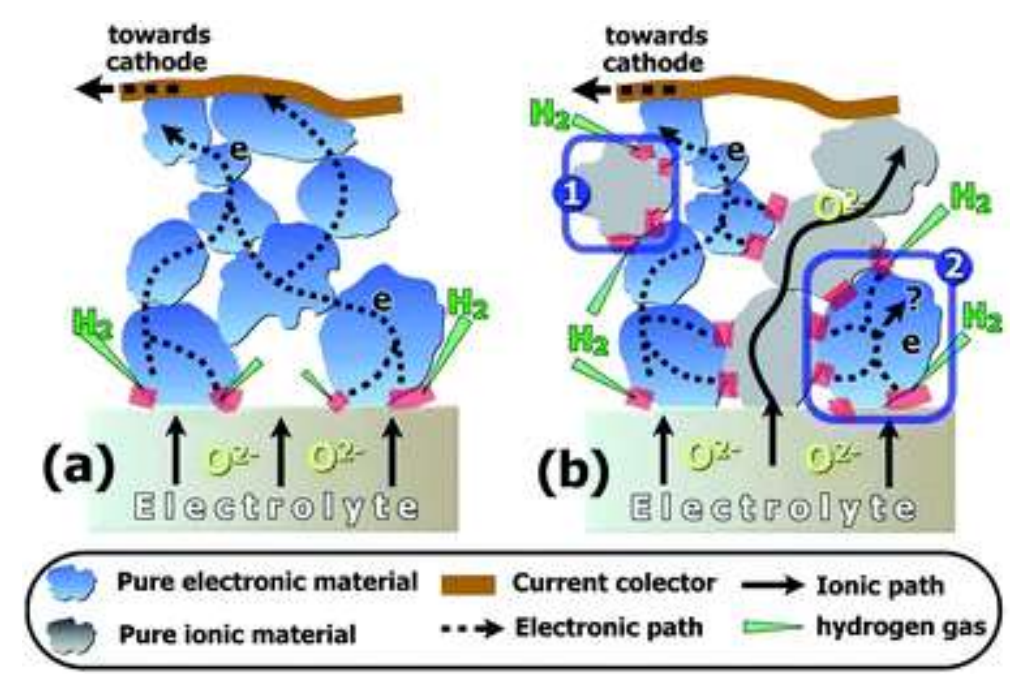

Figure 3.1: Effectiveness of a pure metal (a) versus a mixing an electronic and ionic conductor (b) in the triple phase boundary ${ }^{2}$

$\mathrm{Ni}$ is an attractive material for SOFC anodes because of its low cost and good electrocatalytic activity for $\mathrm{H}_{2}$ oxidation. ${ }^{1} \mathrm{Ni}$ is also a good material for electric conductivity. ${ }^{3}$ 
The anode should, however, be made with the least possible amount of Ni due to its high thermal expansion coefficient relative to all the materials in the cell.

The Nickel (Ni) in a fuel cell is initially introduced as $\mathrm{NiO}$. $\mathrm{NiO}$ is reduced to $\mathrm{Ni}$ with introduction to the fuel stream. It is introduced into the fuel cell initially in the form of $\mathrm{NiO}$ for two roles. One role is to allow for more compatibility with the process and temperatures involved in forming the initial cell. The other is for a more active catalyst surface as it causes a more porous anode due to the volume loss upon $\mathrm{NiO}$ reduction. ${ }^{1}$ The change between $\mathrm{Ni}$ and $\mathrm{NiO}$ causes instability of the Ni/YSZ anode due to redox cycling. This is where oxidation of $\mathrm{Ni}$ back to $\mathrm{NiO}$ can cause failure of the cell due to lattice expansion. ${ }^{3}$

$\mathrm{Ni}$ can coarsen in operation leading to issues such as increased polarization resistance, reduced electrical conductivity, and a change in distribution of Ni relative to the YSZ. ${ }^{1}$ This can lead to cell damage upon reoxidation. ${ }^{1}$ Prior to the initial reduction, the anode consists of $\mathrm{NiO}$ and YSZ. Upon initial reduction the $\mathrm{NiO}$ becomes $\mathrm{Ni}$ creating void spaces throughout the $\mathrm{Ni}$ YSZ material. As the Ni spends time in the reduced state it coarsens. When the material oxidizes again after this coarsened state the resulting $\mathrm{NiO}$ can expand in a more random distribution than it was at initially, causing damage to the cell.

\section{$\underline{\text { Sulfur poisoning of Ni/YSZ anode }}$}

A disadvantage in the conventional Ni/YSZ design is it has a tendency to be poisoned by sulfur. The degradation of the Ni/YSZ anode due to sulfur poisoning consists of an initial rapid degradation followed by a gradual degradation. ${ }^{4}$ The degradation results in a drop of

performance that is only partially recoverable. ${ }^{1,5}$ The tolerance of Ni/YSZ to sulfur is seen to increase with increasing temperature. With the use of impedance spectrometry Matsuzaki 
showed the fuel cell to tolerate sulfur at $0.05,0.5$, and 2 ppm at 800,900 , and $1000 \mathrm{C}$ respectively. Matsuzaki also showed that the times needed for the electrode to recover increased with decreasing temperature.

Using Raman spectroscopy Cheng was able to show that the first rapid stage of degradation to the fuel cell in the sulfur environments are not due to sulfur nickelates forming, but rather are due to the initial adsorption of sulfur onto the electrode surface. ${ }^{5}$ It was seen that $\mathrm{Ni}_{3} \mathrm{~S}_{4}, \beta-\mathrm{NiS}$, and $\mathrm{Ni}_{3} \mathrm{~S}_{2}$ do form but only at lower temperature. There is seen no evidence of these forming at either high operating temperatures, or under the parameters where the fuel cell is cooled rapidly at approximately $70 \mathrm{C} / \mathrm{min}$. In samples where they formed due to slow cooling but were later reheated and cooled rapidly, changes in morphologies and Raman bands that corresponded to the sulfur nickelates disappeared.

\section{Carbon deposition on the Ni/YSZ anode}

Another disadvantage to the Ni/YSZ anodes is carbon deposition on the anode. Transition metals such as nickel have a tendency to catalyze carbon formation from hydrocarbon fuels such as $\mathrm{CH}_{4}{ }^{6}{ }^{\text {This }}$ carbon formation can be detrimental to fuel cell operation. Carbon deposition can both deposit on the surface of the anode covering the $\mathrm{Ni}$, as well as destroying the cell at the active layer. Both of these situations are illustrated in Figure 3.2. 

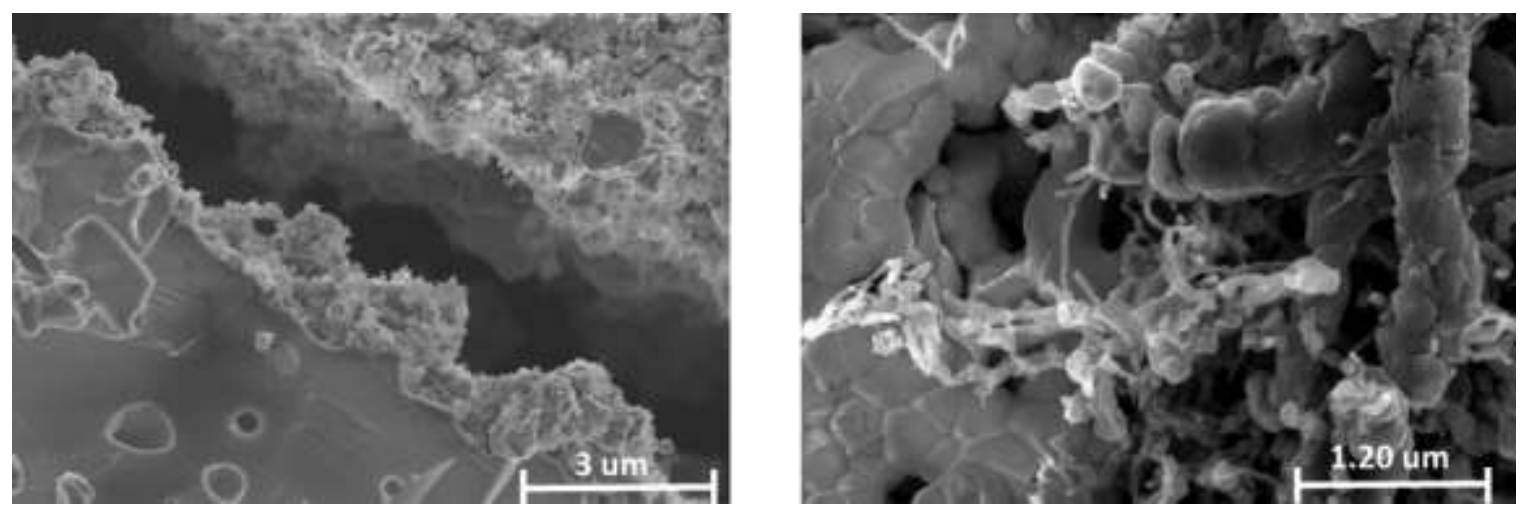

Figure 3.2: (left) Cross section image of failure at the active region due to carbon deposition (right) Surface view carbon deposition on fuel cell

To avoid destruction of the anode, steam should be present to remove carbon from the surface at a faster rate than the carbon can precipitate onto said surface. ${ }^{1}$

Two ways in which carbon deposition can result on an anode are through the Boudard equation and hydrocarbon cracking. ${ }^{1}$ The Boudard equation which is thermodynamically favored between 300 and $700 \mathrm{C}$ is as follows:

$$
2 \mathrm{CO} \rightarrow \mathrm{C}+\mathrm{CO}_{2}
$$

Steam reforming can be done either externally before feeding to the cell or internally on the anode. Internal reforming is attractive, due to less cost associated with not needing an additional reactor. Internal reforming does have the disadvantages of placing large thermal stresses on the cell. The thermal stresses are due to the combining of the endothermic reforming reaction with the exothermic fuel oxidation reaction. ${ }^{3}$ To avoid carbon deposition from natural gas the steam to carbon ratio during steam reforming should be around 1.7. ${ }^{1}$ This reaction was previously given in Equation 4.

Controlling the current density is another way to slow down carbon deposition on the Ni/YSZ anode. ${ }^{16,7}$ Xiao claims this is due to the current density providing oxygen ion flux through the 
electrolyte. This eliminates the carbon deposition caused by the $\mathrm{CH}_{4}$ fuel. The oxygen ion flux eliminates the carbon by equations $6-8 .^{16}$

$$
\begin{aligned}
& \mathrm{C}+\mathrm{O}^{2-} \leftrightarrow \mathrm{CO}+2 e^{-} \\
& \mathrm{H}_{2}+\mathrm{O}^{2-} \leftrightarrow \mathrm{H}_{2} \mathrm{O}+2 e^{-} \\
& \mathrm{C}+\mathrm{H}_{2} \mathrm{O} \leftrightarrow \mathrm{CO}+\mathrm{H}_{2}
\end{aligned}
$$

The lowest current density needed depends on variables such as operating temperature, cell performance, fuel composition, and flow rate. ${ }^{17}$ The greatest amount of carbon will be formed in a cell operating at open circuit voltage (OCV). ${ }^{7}$ Carbon accumulation decreases with increasing voltage.

There are multiple types of carbon deposition that can occur on the Ni/YSZ surface. At lower temperatures carbon fiber formation is favored. According to Xiao carbon fibers grow when there is a balance between dissociation, diffusion, and segregation. This growth lifts nickel particles from the bulk metal pulverizing the nickel metal. The stress from which causes destruction to the anode.

There is a Type I carbon illustrated by Singh. ${ }^{8}$ Temperature programmed oxidation (TPO) analysis showed that this type of carbon burned off between 500 and $800 \mathrm{~K}$ and is associated with hydrogen as $\mathrm{CH}_{\mathrm{x}}$ fragments. This could be seen in the TPO profiles due to the presence of both $\mathrm{CO}_{2}$ peaks and corresponding $\mathrm{H}_{2} \mathrm{O}$ peaks at temperatures between 500 and 800 K. This type of carbon is weakly bonded to Ni/YSZ. The formation of this type of carbon is due to dissociative adsorption of $\mathrm{CH}_{4}$ to $\mathrm{CH}_{\mathrm{x}}$ fragments and monoatomic carbon. They found that the amount of Type I carbon was not significantly affected by the operating conditions of the anode. 
At higher temperatures $\mathrm{CH}_{4}$ becomes more reactive so that the diffusion and segregation cannot keep up with the dissociation of $\mathrm{CH}_{4}$ so that encapsulation of Ni/YSZ occurs instead. This type of carbon, with a graphite structure, causes large stress and is the most destructive. ${ }^{16}$ This would be the Type II carbon deposition described by Singh. Singh showed this type burned off at the 800-1100 K range under TPO analysis. This type of carbon was dependent on operating conditions and was shown to be graphitic carbon in nature. Structural damage to the anode was believed to be due to metal dusting by the graphitic carbon. This is where the particles break down due to graphite growth into the bulk nickel. As it grows into the bulk nickel it disrupts its structure and converts it into dust. Metal dusting was also shown to breakdown the YSZ. In Singh's experiments the structural breakdown from the metal dusting to the YSZ caused the anode thickness to reduce from 100 to approximately 25 microns after 25 hours.

Zhang examined the effects of metal dusting of nickel by transmission electron microscopy (TEM) analysis in more detail. ${ }^{9}$ It was found that on nickel surfaces graphite growth happened preferentially on $\left\{\begin{array}{lll}1 & 1 & 1\end{array}\right\}$ surfaces of the nickel. Though it was still present there was less growth on $\left\{\begin{array}{lll}1 & 1 & 3\end{array}\right\}$ surfaces and very little on $\{002\}$ surfaces. It is noted that a very thin layer of graphite developed on surfaces with an average (002) orientation. They believe that the nickel particles are displaced mechanically in this process by the accumulation of graphite beneath the particles. According to Zhang the only ways to prevent dusting of nickel is to either provide a surface barrier to prevent carbon entry or to disrupt the $\left\{\begin{array}{lllll}0 & 0 & 0 & 1\end{array}\right\} \mathrm{gr} / /\left\{\begin{array}{llll}1 & 1 & 1\end{array}\right\} \mathrm{Ni}$ relationship by alloying. 


\subsection{Chemical solution based anode infiltration of Ni/YSZ anode}

It is important to examine methods of improving the anode so that it is resistant to both sulfur poisoning and carbon deposition. Improvements to $\mathrm{Ni} / \mathrm{YSZ}$ anodes have been attempted by chemical infiltration of solutions into the anode. It has been shown in literature that sulfur poisoning and carbon deposition effects can be mitigated in the anode by modification through processes such as infiltration and various surface modification processes. ${ }^{10,11,12,13}$ This can be done by the nanoparticles covering the nickel sites leaving less room for the adsorption of the carbon or sulfur onto the NiO surface as shown in Figure 3.3. In the case of sulfur poisoning sulfides can form on the infiltrated particles that are not detrimental to cell performance.

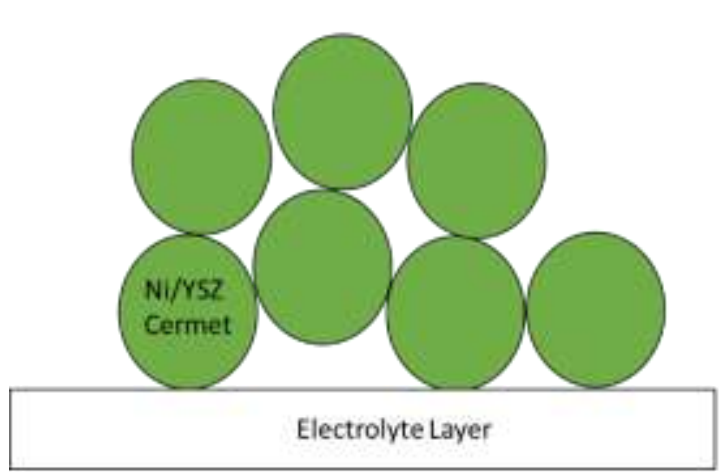

Not Infiltrated Cell

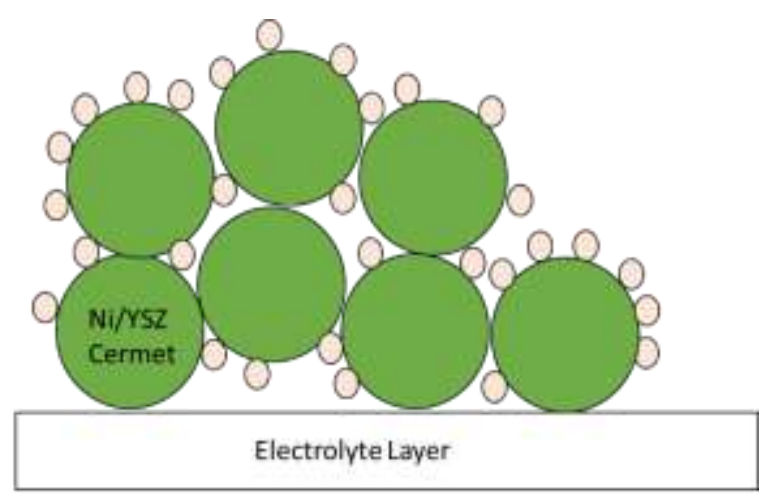

Not Infiltrated Cell

Figure 3.3: Schematic of porous Ni/YSZ anode and infiltration of nano materials on the internal surface of Ni/YSZ Cermet Anode

Choi saw that sulfur does not deposit on Ni/YSZ fuel cell samples sputtered with niobium oxide when testing functional cells with $50 \mathrm{ppm}_{2} \mathrm{~S} .{ }^{12}$ This was attributed to the inflow of oxygen ions from the cathode. It was showed in the study that both the $\mathrm{NbO}_{2}$ and possible sulfides that could form are conductive and catalytically active.

Chen's tests showed that ion impregnation of $10 \% \mathrm{MoO}_{3}$ doped $\mathrm{CeO}_{2}$ into a Ni-YSZ anode could cause the performance of the cell to be higher in $50 \mathrm{ppm} \mathrm{H}_{2} \mathrm{~S}$ than in pure $\mathrm{H}_{2 .}{ }^{13}$ 
This was attributed to the formation of molybdenum sulfides increasing the dissociated hydrogen species as well as a possibility of surface oxides extending the electrochemically active sites. This was also seen to improve coking resistance which was attributed to molybdenum doped ceria. They believe this both prevented methane from affecting the Ni sites, as well as enhanced methane oxidation kinetics.

An important parameter to chemical infiltration is the surfactant used. This can help by forming complexes with the metal cations to aid in the formation of the desired phase and by the use of micelles to control the size of the particles. ${ }^{14}$ Micelles can dissolve and move non polar substances through an aqueous solution. These are molecules having both polar and nonpolar regions that form aggregates where the outer shell consists of polar heads that are in contact with water and the non-polar tails form the interior. They only form once the concentration of the molecules that cause them reach what is called the critical micelle concentration. ${ }^{15}$

Nicholas's team tested fuel cells that were prepared with different types of surfactants in solutions to understand the difference caused by the use of the different surfactants. ${ }^{16}$ They tested a cathode infiltrated with citric acid, Triton X-100, and neither to see if the solution had any effect on the cell and its performance. In the XRD analysis it was found that the citric acid based solutions helped increase the purity by the chelated metal ions remaining homogeneously distributed in the solution during the gelation and drying processes. The team found that the slight improvement in phase purity had little effect on the polarization resistance. They were able to get a lower polarization resistance with a single infiltration of $2.93 \mathrm{M}$ Triton based solution. They attributed this less to the Triton itself and more to the infiltration parameters. This solution was approximately $40 \%$ smaller than the Triton with $0.5 \mathrm{M}$ which itself was approximately $10 \%$ smaller than both the control and citric acid solutions; which were around 
the same size. The author claims the size difference to be on account of a higher nucleation density that is caused by more dissolved nitrates per cathode thickness. For the $2.93 \mathrm{M}$ of Triton sample their hypothesis was that the size difference is due to the single infiltrate and firing cycles. It is believed that this would be capable of enlarging the size of the deposited nanoparticles. The multiple infiltration and firing cycles allow for larger size through more deposition and temperature coarsening. It was also shown that in the two Triton samples the 2.93M showed heavy infiltration, whereas the $0.5 \mathrm{M}$ seemed to show physical isolation of the SSC particles.

Infiltration can also have positive effects in areas such as power density in SOFC systems. It has been shown by Kang that by infiltrating nickel nanoparticles into an YSZ anode performance can be increased due to the catalytic effects of the discretely distributed nanoparticles, as well as an increase to the TPB lengths. ${ }^{17}$ Kang found the increase in power density of the Ni/YSZ anode with infiltration to be less significant as temperature rose. At $700 \mathrm{C}$ they noticed an increase in the power density of the infiltrated anode from 71 to $94 \mathrm{~mW} / \mathrm{cm}^{2}$.

The lifetime of a fuel cell can be increased by the infiltration of transition metals into a nickel anode as demonstrated by Khan. Transition metal infiltration was shown to retard the formation of $\mathrm{Ni}(\mathrm{OH})_{2 .}{ }^{18}$ When $\mathrm{Fe}$, $\mathrm{Co}$, and $\mathrm{Cr}$ were infiltrated into the anode functional layer, it was seen that the concentration of infiltrated particles decreased after long-term tests. Khan attributed this to the formation of hydroxides for the transition metals. This causes the cell to resist the formation of $\mathrm{Ni}(\mathrm{OH})_{2}$ therefore cell life is increased.

In a series of studies conducted by the University of Pennsylvania on preparing ceramic anodes into porous YSZ scaffolds by infiltration Adijanto, Park, Lee ${ }^{19,20,21}$ advantages are seen to 
using an infiltration technique to create the ceramic anodes. One advantage is that infiltration allows for the use of high sintering temperatures to establish ion-conducting channels between the electrolyte and electrode without needing to fire the conductive component of the composite at the same temperatures. Infiltration also allows for the thermal expansion coefficient to be closer to that of the electrolyte by creation of a non-random structure.

Adijanto studied ceramic anodes prepared by infiltration precursor salts of tungsten bronzes into a porous YSZ scaffold. ${ }^{19}$ These produced 40 -wt $\%$ composites of $\mathrm{Na}_{0.8} \mathrm{Nb}_{\mathrm{y}} \mathrm{WO}_{2-\delta^{-}}$ YSZ ( $\mathrm{y}=0,0.3,0.7$, and 1$), \mathrm{K}_{0.5} \mathrm{WO}_{3-} \delta, \mathrm{Cs}_{0.2} \mathrm{WO}_{3-} \delta$, and $\mathrm{Rb}_{0.2} \mathrm{WO}_{3-} \delta . \mathrm{Na}_{0.8} \mathrm{Nb}_{\mathrm{y}} \mathrm{WO}_{2-\delta}-\mathrm{YSZ}$ was found to yield conductivities of $130 \mathrm{~S} / \mathrm{cm}$ at $973 \mathrm{~K}$ and impedance greater than $1.0 \mathrm{ohm} \mathrm{x} \mathrm{cm}{ }^{2}$ in

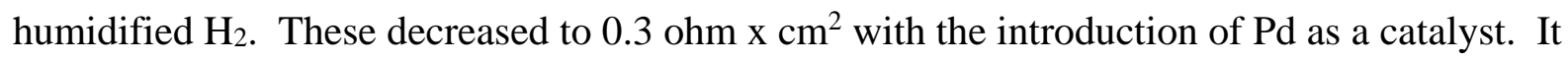
was also seen that the maximum temperature for the use of these bronzes is $1073 \mathrm{~K}$ on account of the reduction of metallic tungsten under reducing conditions.

A similar study led by Park $^{20}$ studied infiltrating La0.7Sr0.3VO $\mathrm{VO}_{3.85}$ into YSZ anodes. Poor performance without the presence of $0.5 \mathrm{vol} \% \mathrm{Pd}$ and 2.8 vol\% ceria catalysts. After the catalysts were added the team obtained an electrode impedance of around $0.1 \mathrm{ohm} * \mathrm{~cm}^{2}$ at $973 \mathrm{~K}$ in humidified $\mathrm{H}_{2}$. A maximum power density of $326 \mathrm{~mW} \mathrm{~cm}{ }^{-2}$ occurred in the LSV doped with $\mathrm{Pd} /$ ceria catalyst at $973 \mathrm{~K}$ in humidified $\mathrm{H} 2$ occurred in $\mathrm{La}_{0.7} \mathrm{Sr}_{0.3} \mathrm{~V}_{1-0.05} \mathrm{O}_{0.25}$. Better power densities in the Vanadium deficient cells were observed than in the vanadium excess cells. The LSV-YSZ was stable in methane but there was evidence for poisoning of the Pd catalyst by the vanadium after high-temperature oxidation.

YSZ infiltrated with 45 wt. \% La0.3Sr0.7 $\mathrm{TiO}_{3}$ was studied by Lee. ${ }^{21}$ The performance was found to be strongly dependent on the calcination temperature. At a calcination temperature of 
$1373 \mathrm{~K}$ the conductivity in humidified $\mathrm{H}_{2}$ was $0.4 \mathrm{~S} / \mathrm{cm}$. When the calcination temperature was raised to $1573 \mathrm{~K}$ it experienced a decrease in conductivity by a factor of 5 respectively. With adding catalysts of Pd and ceria Lee was able to increase the power density of the cells from 20 to $780 \mathrm{~mW} / \mathrm{cm}^{2}$. LST was seen to form particles in open channels of the structure on account of its tendency to avoid wetting.

\subsection{Infiltration of $\mathrm{Ni} / \mathrm{YSZ}$ anode using $\mathrm{BaO}$}

Barium oxide is chosen in this study as an infiltrate to use for SOFC anodes. The reasons for this choice consists of the possibility that surface coverage of $\mathrm{Ni}$ could reduce the available sites for carbon deposition as well as the chance that reactions between the barium oxide and the electrolyte could open up pathways for protonic conduction.

At least two separate teams have studied the effects of Barium infiltration into a SOFC. ${ }^{22,}$

23 The effect of impregnating $10 \%$ weight Barium within a bi-layered NiO-YSZ/NiO- $\mathrm{Ce}_{\mathrm{x}} \mathrm{Gd}_{1-}$ ${ }_{x} \mathrm{O}_{(\mathrm{x}+3) / 2}(\mathrm{GDC})$ anode was investigated by Sandoval. ${ }^{22}$ At $700 \mathrm{C}$ there were shown to be forms of barium nickelates present but as the temperature reached $900 \mathrm{C}$ it was shown to be predominately nickel oxide present. Structural analysis showed that the BZY phase can involve a redistribution of $\mathrm{Y}$ and $\mathrm{Zr}$ between $\mathrm{YSZ}$ and BZY grains. It was claimed that this could possibly cause a decrease in the proton conductivity of the zirconate. Sandoval believed an enhancement in anode kinetics could be attributed to the easy formation and mobility of $\mathrm{OH}^{-}$ groups in either the proton conducting phase or at the surface. Islam's study found that infiltration of Barium oxide into a Ni/YSZ solid oxide fuel cell anode could raise the performance of the cell. ${ }^{23}$ Though the barium oxide effected the conductivity by raising the ohmic resistance of the cell, the polarization resistance decreased causing an increase in the 
performance of the $\mathrm{Ni} / \mathrm{YSZ}$ cell with impregnation of $\mathrm{BaO}$. The best weight percent of $\mathrm{BaO}$ infiltration tested by Islam was 5\% weight.

Yang showed it possible to create a surface with nanostructured $\mathrm{BaO} / \mathrm{Ni}$ interfaces that would promote carbon removal without impeding charge transfer across the $\mathrm{BaO} / \mathrm{Ni}$ interfaces and surfaces of the anode. ${ }^{11}$ This is due to the interfaces ability to both adsorb water and facilitate water-mediated carbon removal reactions. The cell was created by introducing $\mathrm{BaO}$ through deposition during the firing of a SDC buffer layer so it would react to form NiO-BaO compounds. These compounds were later reduced to $\mathrm{BaO}$ nanoislands distributed on the $\mathrm{Ni}$ surface. Yang claimed the problem with creating a continuous $\mathrm{BaO}$ film being that it would block the electron paths in the anode. Yang obtained a maximum power density of $0.88 \mathrm{~W} \mathrm{~cm}^{-2}$ in dry $\mathrm{C}_{3} \mathrm{H}_{8}$ at $750^{\circ} \mathrm{C}$, as well as stability of power output for greater than 100 hours at a constant current density of $500 \mathrm{~mA} \mathrm{~cm}{ }^{-2}$.

An advantage to using barium oxide as an infiltrate is the possibility of it reacting with the electrolyte of the fuel cell. The reaction could form the $\mathrm{BaZrO}_{3}$ channels that literature shows to be a good proton-conducting electrolyte for SOFC applications. ${ }^{24}$ It is commonly believed that the use of proton-conducting electrolytes can decrease the operating temperature of SOFCs into intermediate temperature range due to the low activation energy and good ionic conductivity of such systems.

Examples of proton conduction with barium is seen in barium cerium based compounds. Yano proposed that the anode overpotential could be reduced by enhancing the adsorption of hydrogen or the transfer of protons using a proton-conducting material. ${ }^{25}$ This would be due the expansion of the reaction area in the anode that results from the oxide ions being able to easily 
react with the protons or adsorbed hydrogen on the entire surface of the proton-conducting material. Yano studied an anode composed of a proton conductor Barium-Cerium/Yttrium Oxide (BCY) ( $\left.\mathrm{BaCe}_{0.8} \mathrm{Y}_{0.2} \mathrm{O}_{3-\delta}\right)$. The material was included in a Ni/GDC anode with the ratio of GDC to BCY being 0:100, 50:50, 90:10, and 100:0 vol. \%. They showed that adding 10\% BCY into a GDC anode was the best tested combination as it was shown to reduce the anode overpotential by half. There was no network structure in the BCY particles so Yano theorized this was most likely due to the BCY particle causing either a reaction enhancement, hydrogenadsorption, or increasing the catalytic activity per unit TPB.

A barium cerate proton conductor for $\mathrm{H}_{2} \mathrm{~S}$ tolerance in solid oxide fuel cells was tested by Tan. ${ }^{26}$ They found a high conductivity of $10^{-2} \mathrm{~S} \mathrm{~cm}^{-1}$ for the formula $\mathrm{BaCe}_{0.425} \mathrm{Zr}_{0.475} \mathrm{Y}_{0.1} \mathrm{O}_{3}$ and a maximum power density of $1.55 \mathrm{~mW} \mathrm{~cm}^{-2}$ for $\mathrm{MoS}_{2}-\mathrm{BaCe}_{0.425} \mathrm{Zr}_{0.475} \mathrm{Y}_{0.103-\sigma-}$ with a $\mathrm{BaCe}_{0.425} \mathrm{Zr}_{0.475} \mathrm{Y}_{0.103-\sigma}$ electrolyte. The problem with this cell was that the separation between the electrode and electrolyte caused ohmic loss suggesting the need to create a more compatible anode material.

Barium oxide was used on account of the possibility of increased performance and enhancement in anode kinetics seen by other researchers. ${ }^{22,23}$ It was also studied due to the possibility of the formation of proton-conducting channels opening up if reactions take place between the electrolyte and infiltrate. ${ }^{24}$ This experiment deals with the optimization of the infiltration parameters of barium oxide into the anode.

The barium oxide was infiltrated by creation of a barium nitrate solution for infiltration into electrolyte supported solid oxide fuel cells. Barium nitrate was mixed in quantities measured in grams of barium nitrate/100 mL water with either Triton added as a surfactant or 
citric acid added as a chelating agent. Three chemistries were attempted and imaged in infiltrated cells. The starting chemistry of the solution was taken with respect to solubility tables. ${ }^{27}$ The solubility tables suggested that barium nitrate was soluble in the amount of 8.7 $\mathrm{g} / 100 \mathrm{~mL}$ water at $20 \mathrm{C}$ and $1 \mathrm{~atm}$. The chemistries of the infiltrated solutions consisted of the sample BaO-3 which used approximately $3 \%$ weight surfactant and $8 \mathrm{~g} / 100 \mathrm{~mL}$ Barium nitrate, BaO-4 consisted of $5 \mathrm{~g} / 100 \mathrm{~mL} \mathrm{H}_{2} \mathrm{O}$ with $3 \%$ weight surfactant, and $\mathrm{BaO}-5$ consisted of $3 \mathrm{~g} / 100$ $\mathrm{mL}$ water and used citric acid as a chelating agent instead of surfactant.

The fuel cell was then broken in approximately four pieces with small left over pieces to be used as SEM control for the initial portion of the experiment. To measure the amount of infiltration in the fuel cell the weight of the total fuel cell was first taken before infiltration with a high accuracy balance that is accurate up to six decimal places. The cathode of the cell was then taped to prevent infiltration of the barium nitrate into the cathode of the cell. Next, the barium nitrate was mixed using an ultrasonic until the barium nitrate fully dissolved into the solution. $\mathrm{BaO}$ samples 1 and 2 did not fully dissolve into the solution, therefore were not infiltrated into a cell. The sample was infiltrated by putting drops of solution over anode (green) side. For the BaO-3 experiment the sample was placed into the oven for approximately 2 hours. After the 2 hours the sample was measured again using the high accuracy balance. The sample was then infiltrated and placed into the oven again to add more infiltration to the cell. After the sample was placed into a furnace to calcine at $600 \mathrm{C}$ for 2 hours.

BaO-4 and $\mathrm{BaO}-5$ did not use the oven at $90 \mathrm{C}$ step to infiltrate the samples. It was decided instead to do a single infiltration at a higher calcination temperature as it was believed the $600 \mathrm{C}$ may not be a high enough temperature to convert the barium nitrate into barium oxide. Both $\mathrm{BaO}-4$ and $\mathrm{BaO}-5$ was prepared by dropping solution on the anode portion of the cell to 
cover the whole anode. After this was done the cell was placed into an oven to calcine at $800 \mathrm{C}$ for 2 hours.

The total weights taken after infiltration with the tape, including the total weight change between the fuel cell without the tape initially vs the fuel cell without the tape after calcination is shown in Table 3.1.

Table 3.1: Infiltrations and Mass Gains of $\mathrm{BaO}-3$

\begin{tabular}{|l|r|r|}
\hline & grams & $\begin{array}{l}\text { difference in grams (from } \\
\text { initial) }\end{array}$ \\
\hline Total mass & 0.33127 & \\
\hline 1st infiltration (2 drops) & 0.33166 & 0.00039 \\
\hline 2nd infiltration (2 drops) & 0.33381 & 0.00254 \\
\hline 3rd infiltration (1 drop) & 0.3345 & 0.00323 \\
\hline After calcine & & \\
\hline initial weight w/o tape & 0.31914 & \\
\hline & 0.31747 & 0.00167 \\
\hline
\end{tabular}

Due to charging in the sample the samples were coated. $\mathrm{BaO}-3$ was coated with platinum, $\mathrm{BaO}-4$ and $\mathrm{BaO}-5-1$ were coated with carbon, and $\mathrm{BaO}-5-2$ was coated with $\mathrm{Au}$. It could be seen in the BaO-3 samples that the surface of the cells resembled crystallites instead of particles. To try and get particles on the surface of the cells instead of crystallites it was decided to prepare two more chemistries with a lower concentration of barium nitrate mixed into the solution. The first sample was $\mathrm{BaO}-4$ infiltrated with $5 \mathrm{~g}$ barium nitrate $/ 100 \mathrm{~mL} \mathrm{H}_{2} \mathrm{O}$ and calcined at $800 \mathrm{C}$ for 2 hours.

As the cell itself was not symmetrical a difficulty arose in taking the infiltration weight of barium oxide in the fuel cell. This was due to the size of the cathode being too small relative to the YSZ for taking the average diameter of the cell that is typically done with non-symmetrical circular shapes. To get an accurate infiltration measurement a picture of the cell was taken 
parallel to the surface of the cell and uploaded into Autocad Inventor. This picture was traced in the software and scaled to a reference dimension that was taken of the cell. A feature of the software that allows for the area within a shape to be calculated was then used to determine the area of the fuel cell. The infiltration weight of the cell was determined by the following equation:

$$
\frac{\text { Wt after infiltration }}{\frac{1}{2}(\text { Total mass }- \text { YSZ mass })} \times 100=w t \% \text { infiltration of barium oxide }
$$

Triton $\mathrm{X}-100$ at $8 \mathrm{~g}$ barium nitrate/ $100 \mathrm{~mL} \mathrm{H}_{2} \mathrm{O}$ formed large planar $\mathrm{BaO}$ particles on the $\mathrm{Ni}$ as shown in Figure 5 for $\mathrm{BaO}-3$. These particles existed both parallel and perpendicular to the anode surface.

For the $\mathrm{BaO}-4$ sample at $5 \mathrm{~g}$ barium nitrate/100 $\mathrm{mL} \mathrm{H}_{2} \mathrm{O}$ there were still a few large planar sections of barium oxide but many more particulates present. There were also some grains on which the barium oxide particles aggregate into slightly larger particles, therefore not giving the desired homogeneous distribution of barium oxide particles desired on the surface of the anode.

The decision was made to test whether the use of citric acid as a chelating agent instead of the surfactant Triton would aid in breaking down the $\mathrm{BaO}$ particles. This was done due to the use of citric acid in the literature. ${ }^{16}$ In this sample that barium nitrate was also infiltrated in a smaller quantity than in both $\mathrm{BaO}-3$ and $\mathrm{BaO}-4$ samples. As can be seen in Figure 3.4, $\mathrm{BaO}-5$ which consisted of $3 \mathrm{~g} \mathrm{BaO} / 100 \mathrm{~mL} \mathrm{H}_{2} \mathrm{O}$ and citric acid at a 1:1 molar ratio of citric acid to $\mathrm{BaO}$ successfully broke up the $\mathrm{BaO}$ particles resulting in a near homogenous distribution of barium oxide on the anode surface. There were however dendrites present in $\mathrm{BaO}-5$ as shown in Figure 
3.5. Larger dendrites were also present in $\mathrm{BaO}-4$ on the anode surface. It should be noted however that the size of the dendrites were much smaller on the $\mathrm{BaO}-5$ infiltrated samples than on the BaO-4 infiltrated samples. Based SEM images the size of the particles were seen to average between 45 and $60 \mathrm{~nm}$. It was observed that the barium oxide forms regions of dendritic growth of $\mathrm{BaO}$ on the anode surface as can also been seen in the images.
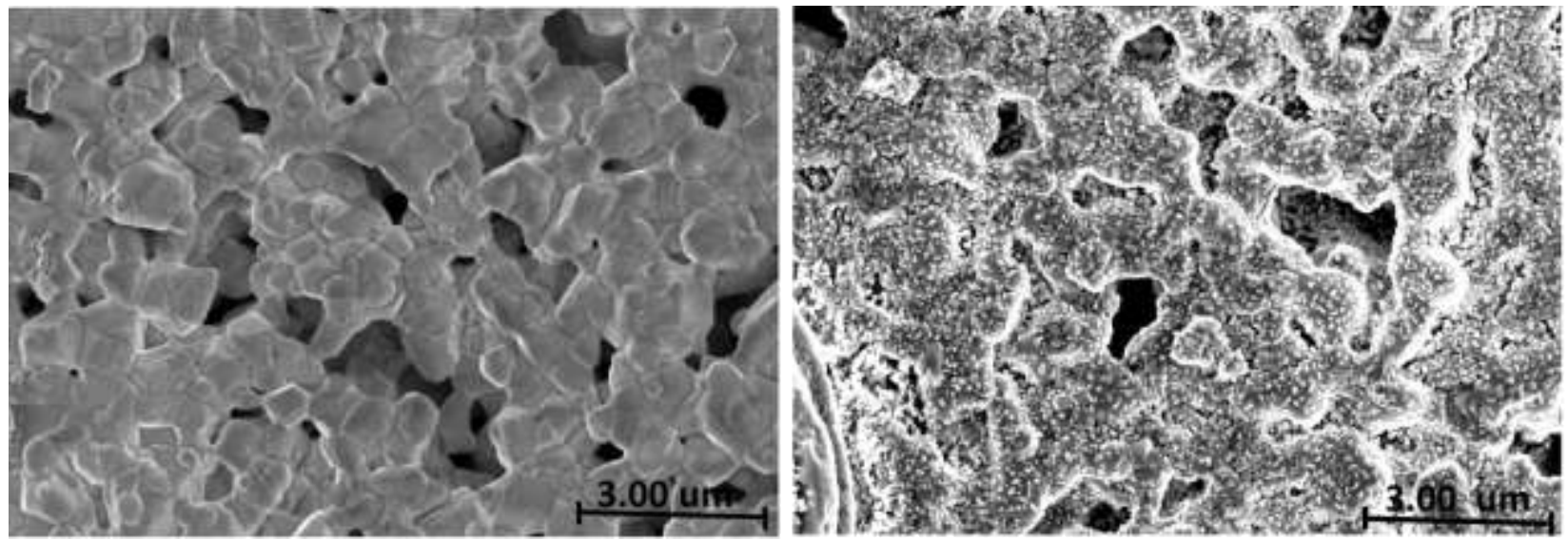

Figure 3.4: Surface of Ni/YSZ anode before infiltration (left) surface of Ni/YSZ anode with optimal barium oxide concentration (right)

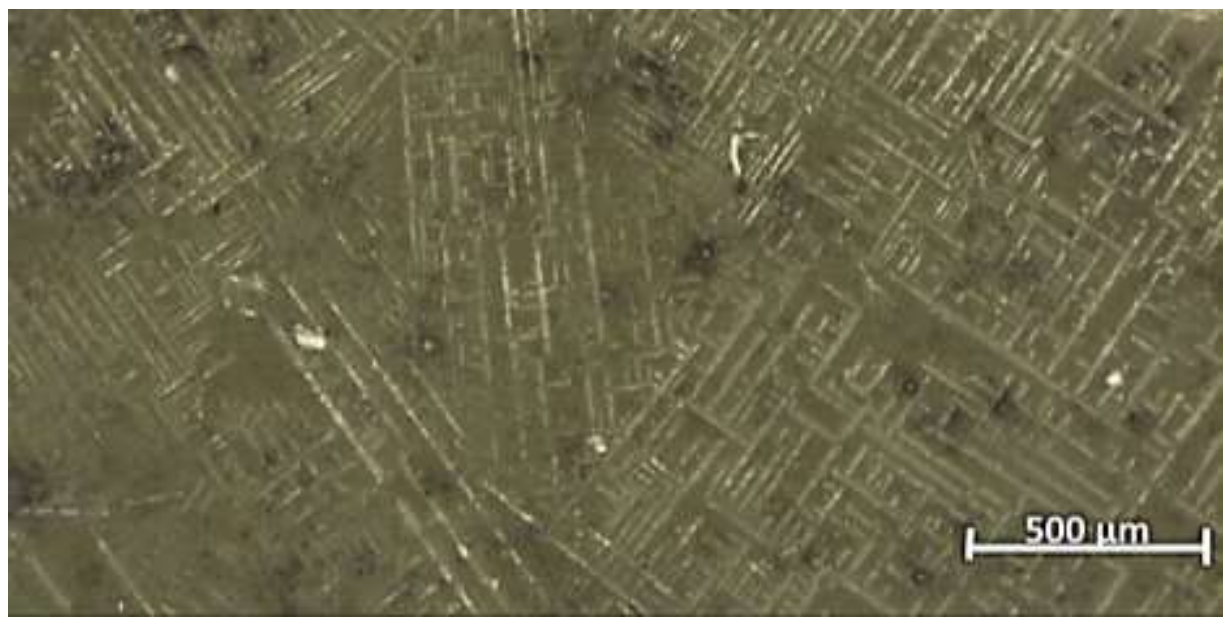


Figure 3.5: Light microscopy images of dendrites present on the surface of a $\mathrm{BaO}-5-1$

\section{infiltrated anode}

The chemistry of the cells were confirmed using EDS. The spectrum for $\mathrm{BaO}-5-1$ is shown in Figure 3.6. This spectrum confirms the chemistry of the sample to indeed contain barium, nickel, carbon, oxygen, and the electrolyte zirconium. It also confirms the removal of nitrogen during the calcination phase.

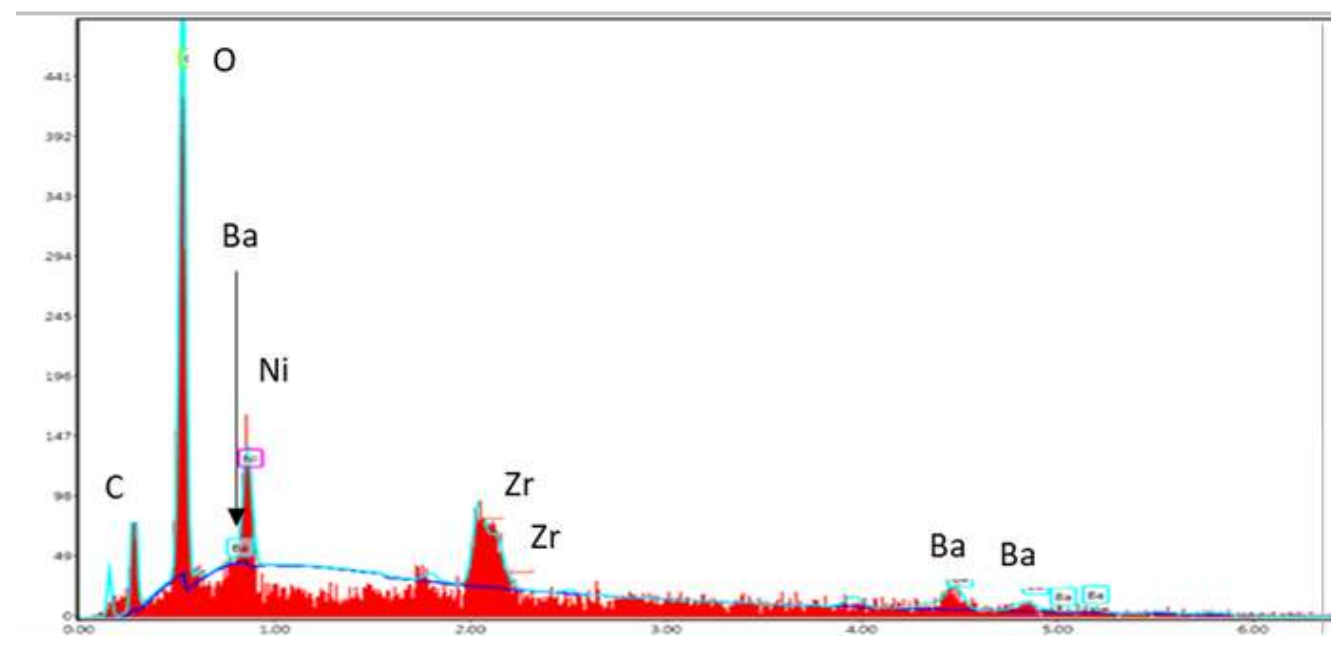

Figure 3.6: EDS spectrum of BaO-5-1

To confirm the barium oxide was infiltrated into the whole cell and not just the surface cross section TEM images had to be taken. In examination of the cross sectional TEM images in Figure 3.7 it is seen that the $\mathrm{BaO}-5$ cell does have infiltrated particles throughout the anode. Infiltration into the active layer is further confirmed by the corresponding EDS data presented in Figure 3.7. 

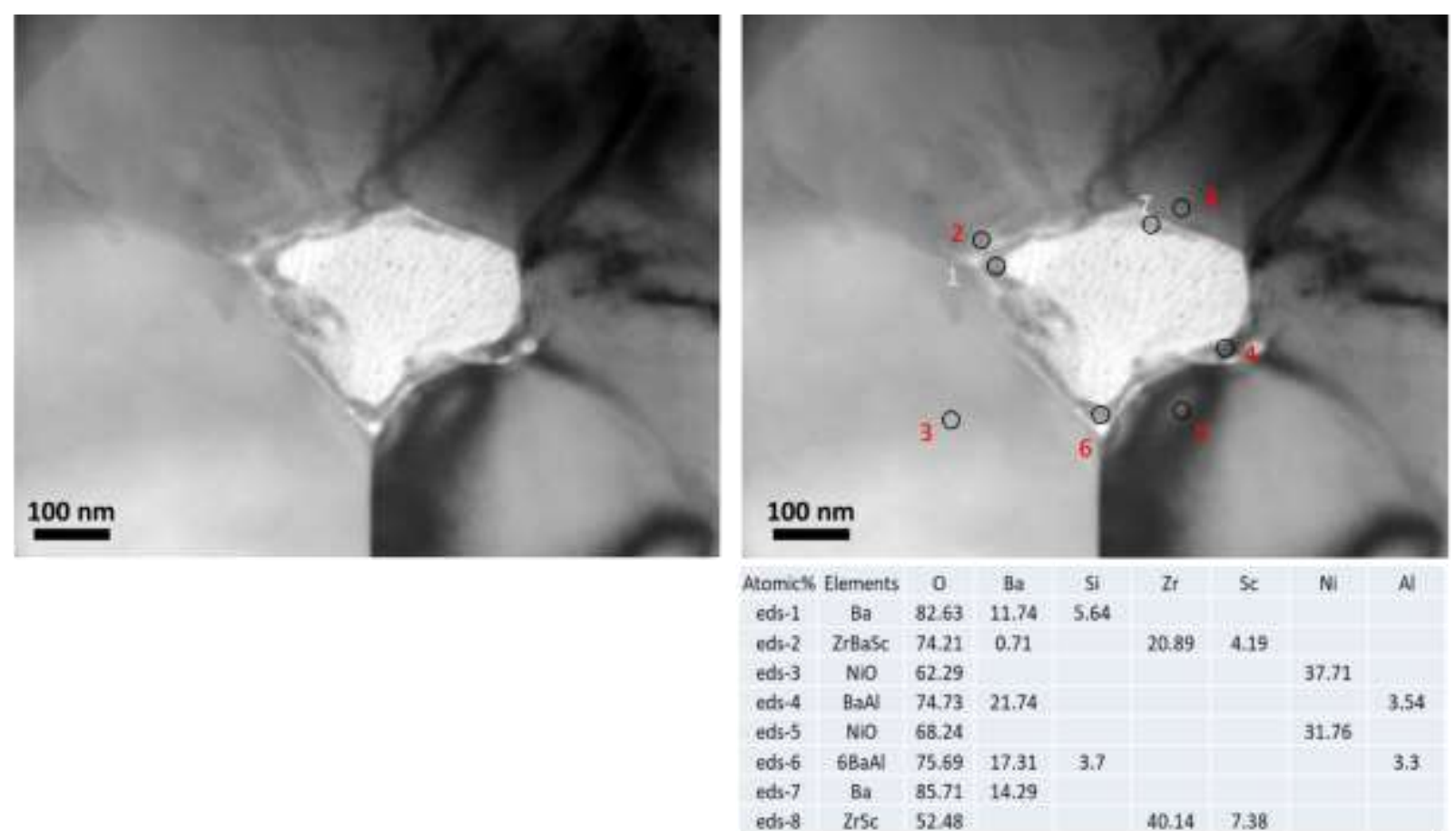

Figure 3.7: TEM of barium oxide infiltration into active layer (left) and corresponding EDS of TEM image (right)

Summary of the effect of $\mathrm{BaO}$ infiltration on the Ni/YSZ anode

A successful infiltration technique for a barium oxide solution into the anode of the SOFC was developed. The infiltration consisted of an $800 \mathrm{C}$ for 2 hour calcination step. The infiltrated solution concentration was optimized to a $3 \mathrm{~g} / 100 \mathrm{~mL}$ DI water barium nitrate solution that used citric acid for a chelating agent. The presence of barium oxide, along with its even distribution on the cell surface and infiltration into the active layer was confirmed with SEM, TEM, and EDS analysis. 


\footnotetext{
${ }^{1}$ In Kendall, K., \& In Kendall, M. (2016). High-temperature solid oxide fuel cells for the 21 st century: Fundamentals, design and applications.

${ }^{2}$ Ruiz-Morales, J., Marrero-Lâopez, D., Gâalvez-Sâanchez, M., Canales-Vâazquez, J., Savaniu, C., \& Savvin, S. (2010). Engineering of materials for solid oxide fuel cells and other energy and environmental applications. Energy \& Environmental Science, 3(11), 1670-1681.

${ }^{3}$ In Jiang, S. P., \& In Yan, Y. (2013). Materials for high-temperature fuel cells.pg 23-25

${ }^{4}$ Matsuzaki, Y., \& Yasuda, I. (January 01, 2000). The poisoning effect of sulfur-containing impurity gas on a SOFC anode: Part I. Dependence on temperature, time, and impurity concentration. Solid State Ionics, 132, $261-269$.
}

${ }^{5}$ Cheng, Z., \& Liu, M. (January 01, 2007). Characterization of sulfur poisoning of Ni-YSZ anodes for solid oxide fuel cells using in situ Raman microspectroscopy. Solid State Ionics, 178, 13, 925-935.

${ }^{6}$ Xiao, J., Xie, Y., Liu, J., \& Liu, M. (December 05, 2014). Deactivation of nickel-based anode in solid oxide fuel cells operated on carbon-containing fuels. Journal of Power Sources, 268, 508-516.

${ }^{7}$ Singh, A., Islam, S., Buccheri, M. A., \& Hill, J. M. (October 01, 2013). Influence of experimental conditions on reliability of carbon tolerance studies on Ni/YSZ SOFC anodes operated with methane. Fuel Cells, 13, 5, 703-711.

${ }^{8}$ Singh, A., \& Hill, J. M. (September 15, 2012). Carbon tolerance, electrochemical performance and stability of solid oxide fuel cells with $\mathrm{Ni} /$ yttria stabilized zirconia anodes impregnated with $\mathrm{Sn}$ and operated with methane. Journal of Power Sources, 214, 185-194

${ }^{9}$ Zhang, J., Munroe, P., \& Young, D. J. (January 01, 2008). Microprocesses in nickel accompanying metal dusting. Acta Materialia, 56, 1, 68-77.

${ }^{10}$ L., S., Z., L., Z., \& Z. (2012). Sulfur tolerance improvement of ni-YSZ anode by alkaline earth metal oxide baO for solid oxide fuel cells. Electrochemistry Communications, 19(1), 63-66. doi:10.1016/j.elecom.2012.03.027

${ }^{11}$ Yang, L., Choi, Y., Qin, W., Chen, H., Blinn, K., Liu, M., Liu, P., ... Liu, M. (January 01, 2011). Promotion of water-mediated carbon removal by nanostructured barium oxide/nickel interfaces in solid oxide fuel cells. Nature Communications, 2.

${ }^{12}$ C., W., C., \& L. (2008). Surface modification of ni-YSZ using niobium oxide for sulfur-tolerant anodes in solid oxide fuel cells. Journal of the Electrochemical Society, 155(5), 454. doi:10.1149/1.2844366

${ }^{13}$ Chen, Y., Bunch, J., Jin, C., Yang, C., \& Chen, F. (2012). Performance enhancement of ni-YSZ electrode by impregnation of mo0.1Ce0.9O2 $\delta$. Journal of Power Sources, 204, 40-45. doi:10.1016/j.jpowsour.2012.01.019

${ }^{14}$ Kan, W. H., Samson, A. J., \& Thangadurai, V. (January 01, 2016). Trends in electrode development for next generation solid oxide fuel cells. J. Mater. Chem. A, 4, 46, 17913-17932.

${ }^{15}$ Micelles. University Federico II of Naples Italy. Web. February 22, 2017. http://www.whatischemistry.unina.it/en/micella.html 
${ }^{16}$ Nicholas, J. D., \& Barnett, S. A. (January 01, 2010). Measurements and Modeling of Sm[sub 0.5]Sr[sub 0.5] CoO[sub 3-x]-Ce[sub 0.9] Gd[sub 0.1]O[sub 1.95] SOFC Cathodes Produced Using Infiltrate Solution Additives. Journal of the Electrochemical Society, 157, 4.)

${ }^{17}$ Kang, L. S., Park, J. L., Lee, S., Jin, Y. H., Hong, H. S., Lee, C. G., \& Kim, B. S. (January 01, 2014). Enhanced low-temperature power density of solid oxide fuel cell by nickel nanoparticle infiltration into pre-fired Ni/yttriastabilized zirconia anode. Journal of Nanoscience and Nanotechnology, 14, 12, 8974-7.

${ }^{18}$ Khan, M. S., Lee, S. B., Song, R. H., Lee, J. W., Lim, T. H., \& Park, S. J. (January 01, 2015). Effect of infiltrated transition metals on nickel morphology change and area-specific resistance of Ni-YSZ based SOFC anode during long-term operation. Journal of Electroceramics, 35, 81-89.

${ }^{19}$ Adijanto, L., Küngas, R., Park, J., Vohs, J. M., \& Gorte, R. J. (January 01, 2011). SOFC anodes based on infiltration of tungsten bronzes. International Journal of Hydrogen Energy, 36, 24, 15722-15730

${ }^{20}$ Park, J.-S., Hasson, I. D., Gross, M. D., Chen, C., Vohs, J. M., \& Gorte, R. J. (January 01, 2011). A highperformance solid oxide fuel cell anode based on lanthanum strontium vanadate. Journal of Power Sources, 196, 18, 7488-7494.

${ }^{21}$ Lee, S., Kim, G., Vohs, J. M., \& Gorte, R. J. (January 01, 2008). SOFC Anodes Based on Infiltration of La0.3Sr0.7TiO3. Journal of the Electrochemical Society, 155, 11.)

${ }^{22}$ Sandoval, M. V., Matta, A., Matencio, T., Domingues, R. Z., Ludwig, G. A., De, A. K. M., de, F. M. C., ... Gauthier, G. H. (August 01, 2014). Barium-modified NiO-YSZ/NiO-GDC cermet as new anode material for solid oxide fuel cells (SOFC). Solid State Ionics, 261, 36-44.

${ }^{23}$ Islam, S., \& Hill, J. M. (January 01, 2014). Barium oxide promoted Ni/YSZ solid-oxide fuel cells for direct utilization of methane. J. Mater. Chem. A, 2, 6, 1922-1929.

${ }^{24}$ Bi, L., Da'as, E., \& Shafi, S. (2017). Proton-conducting solid oxide fuel cell (SOFC) with y-doped baZrO3 electrolyte. Electrochemistry Communications, 80, 20-23.

${ }^{25}$ YANO, S., NAKAMURA, S., HASEGAWA, S., IHARA, M., \& HANAMURA, K. (2009). Solid oxide fuel cell with anodes using proton conductor (Barium-Cerium/Yttrium oxide). Journal of Thermal Science and Technology, 4(3), 431-436. doi:10.1299/jtst.4.431

${ }^{26}$ Tan, W., Zhong, Q., Miao, M., \& Qu, H. (2009). $\mathrm{H}_{2} \mathrm{~S}$ solid oxide fuel cell based on a modified barium cerate perovskite proton conductor. Ionics, 15(3), 385-388. doi:10.1007/s11581-008-0278-0

${ }^{27}$ Barium Nitrate. PubChem Open Chemistry Database. Web. March 17, 2018. https://pubchem.ncbi.nlm.nih.gov/compound/barium_nitrate\#section=Solubility 


\section{Chapter 4: LSM/YSZ cathode and cathode infiltration}

\subsection{State of the art LSM/YSZ cathode design advantages and disadvantages}

Lanthanum strontium manganese (LSM) is a material of the formula $\mathrm{La} 0.8 \mathrm{Sr} 0.2 \mathrm{MnO}_{3}$ that is commonly used in high-temperature fuel cells. The base form of this material is $\mathrm{LaMnO}_{3}$. The $\mathrm{LaMnO}_{3}$ is then doped with $\mathrm{Sr}$ to give it better properties for SOFC fuel cell application. ${ }^{1}$

LSM in pure form exhibits an orthorhombic crystal structure at $25 \mathrm{C}$ which changes to a rhombohedral at temperatures greater than $600 \mathrm{C}^{2} \mathrm{LSM}$ is a perovskite oxide $\mathrm{ABO}_{3}$ structure where the $\mathrm{La}^{3+}$ ions at the A-site are partially substituted by $\mathrm{Sr}^{2+}$ ions. $\mathrm{LaMnO}_{3}$ exhibits an increase in electrical conductivity as it is doped with Sr. This is due to the material being a ptype semiconductor where there are holes between the $\mathrm{Mn}^{3+}$ and $\mathrm{Mn}^{4+}$ cations. When the material is doped with $\mathrm{Sr}$ these holes increase thus increasing the electrical conductivity. ${ }^{2}$

After it is doped with Sr LSM exhibits good electrical conductivity, catalytic activity for oxygen reduction, thermal and chemical stability, as well as having good mechanical properties at high temperatures ${ }^{1}$. The material also has the advantage of having a good chemical compatibility with stabilized zirconia electrolyte. ${ }^{1}$

It has been shown by researchers that the polarization resistance $\left(\mathrm{R}_{\mathrm{p}}\right)$ of a LSM-YSZ cermet is around $1.47 \Omega^{*} \mathrm{~cm}^{23}$ per electrode in a symmetric cell configuration. Disadvantages of the material system includes negligible ionic conductivities, oxygen reduction that is limited to the triple phase boundary (TPB) region, and an increase in electrode polarization resistance which makes the LSM not practical at temperatures less than $700 \mathrm{C}$. 
The oxygen reduction at SOFC cathodes involves oxygen adsorption and dissociation at the surface by the breaking of the covalent bond in the $\mathrm{O}_{2}$ molecules, oxygen reduction, transfer of the reduced oxygen ion within the cathode, and transport of the anion across the interface of the cathode and electrolyte..$^{5}$

There are three possible routes of oxygen anion transport through the cathode. ${ }^{4}$ These routes include bulk path, surface path, and electrolyte surface path. The path that the cathode follows is the path with the fastest rate-determining step. When the reaction and transport rates are faster, the polarization resistance of the cell is lower.

Singhal showed the crystallographic transformation temperature of LSM to strongly depend on the oxygen stoichiometry. The oxygen stoichiometry effects the mean manganese valence, therefore as oxygen content increases there should be a rapid decrease in the crystallographic transformation temperature. ${ }^{2}$ For the system measured in his lab at 700 and 800 $\mathrm{C}$ respectively he records the isotope oxygen diffusion coefficient to be $3.1 \times 10^{-15}$ and $4.00 \times 10^{-}$ ${ }^{16} \mathrm{D}^{*} \mathrm{~cm}^{2} \mathrm{~s}^{-1}$, and the oxygen surface exchange coefficients to be $1.01 \times 10^{-9}$ and $5.62 \times 10^{-9}$ $\mathrm{k}^{*}\left(\mathrm{cms}^{-1}\right){ }^{5}$

An area of concern for the cathode material in SOFC systems is the thermal expansion of the cathode. In order to minimize stress during the operation and fabrication of the cell the thermal expansion must be matched closely with the SOFC electrolyte and interconnect. The thermal expansion of the LSM that was done in lab is given by Singhal as $11.3 \times 10^{-6} \mathrm{~K}^{-1}$. $^{2}$ 


\section{$\underline{\text { Polarization resistance of symmetric cells }}$}

A type of resistance that is attempted to be lowered by infiltration of symmetric cell cathodes is polarization resistance. The lower the temperatures solid oxide fuel cells operate at the lower the overall electrochemical performance due to increased cell resistance mostly from an increase in the cell polarization resistance. ${ }^{6,7}$ Polarization resistance can be divided into

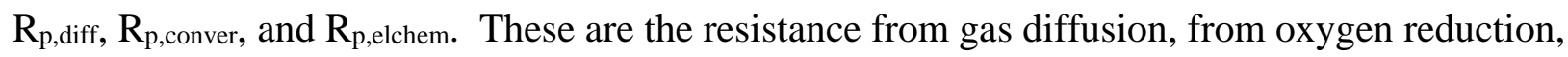
and from the limiting electrochemical and chemical processes respectively. ${ }^{2}$

The ohmic resistance in a SOFC is caused by the conduction of the ions and the electrons in the cell, whereas the overpotential is caused due to the reactions occurring in the anode and cathode of the cell. To increase the power density of the cell one must decrease the overpotential and the ohmic resistance in the cell. ${ }^{8}$

Electrochemical impedance spectroscopy (EIS) is a method used to look at losses in a SOFC and to give insight into which components and processes degrade during the operation of the fuel cell. ${ }^{9}$ At open circuit potential there is no net current flow. In this type of measurement a potentiostat will shift the potential away from open circuit potential allowing electrochemical reactions to flow. The potential will then measure the rate at which the electrons move. Frequency is used to probe different processes due to the dependence of the different processes on frequency. This can be separated to get the contributions of each process such as the contributions from polarization resistance and that from series resistance. ${ }^{10}$ Nielsen gives an example of obtained impedance spectra from 200-900 C in LSM-YSZ and LSM-CGO symmetric cells along with the parameters used with a Solatron 1260 FRA. The parameters used was in the experiment was a frequency range of $1 \mathrm{MHz}-1 \mathrm{mHz} .{ }^{9}$ An EIS perturbation amplitude was used at 
$30 \mathrm{mV}$ RMS. Nielsen stated that for this kind of measurements there can be a need to correct for wire inductance.

In studying the EIS of a symmetric cell consisting of 50/50 wt. \% $\mathrm{La}_{0.58} \mathrm{Sr}_{0.4} \mathrm{Fe}_{0.8} \mathrm{Co}_{0.2} \mathrm{O}_{2-\delta}$ (LSCF and $\mathrm{Ce}_{0.9} \mathrm{Gd}_{0.1} \mathrm{O}_{1.95}(\mathrm{CGO} 10)$ and the same material in an anode supported cell $\mathrm{Hjelm}$ found that the polarization resistance increased with decreasing $\mathrm{pO}_{2} .{ }^{11} \mathrm{Hjelm}$ also saw that the polarization resistance decreases with increasing temperature, when measuring the change in polarization resistance for the temperature range $550-850 \mathrm{C}$. Hjelm's experimental design consisted of painting Pt paste to both sides of four $0.4 \times 0.4 \mathrm{~cm}^{2}$ symmetric cells to obtain a good electrical contact between the cell's cathode and a Pt mesh. EIS parameters used consisted of a frequency range of $100 \mathrm{kHz}-0.1 \mathrm{~Hz}$ at open circuit voltage (OCV). The $\mathrm{R}_{\mathrm{p}}$ experienced passivation, in that it increased with time. Hjelm's team found the $\mathrm{R}_{\mathrm{p}}$ in air at $750 \mathrm{C}$ in the symmetric cells to be $0.03 \Omega \mathrm{cm}^{2}$ for the full cell at zero bias and $745 \mathrm{C}$ the polarization resistance was seen to be $0.26 \Omega \mathrm{cm}^{2}$.

$\underline{\text { Symmetric fuel cell }}$

EIS measurements to study cathode materials are often taken in a symmetrical fuel cell configuration. These can be used to measure electrode performance in detail. ${ }^{2}$ In this configuration a platinum mesh or conductive paste is used for electrode contact. A highly conductive wire made of materials such as silver or platinum comes out of each side of the cell. One of these wires measures current while the other determines the potential. The advantage of this type of test is it is known what the source of the electrode properties is because both are the same material. The disadvantage is that this kind of test can only be done close to the open 
current potential. This is because the electrode loss here does not depend on if the cell is polarized anodically or cathodically. ${ }^{2}$

Symmetric fuel cells can advantageous in SOFC use due to its ability to reduce the production cost of manufacturing of fuel cells greatly. This reduction is on account that only one material would be required to be manufactured for both the cathode and the anode. For this same reason the manufacturing procedure would have less problems because it allows the fuel cell to be assembled in a single thermal treatment. This type of assembly reduces problems that have to do with the interdiffusion between the cell components. Another advantage of using symmetric fuel cells is related to the sulfur poisoning and carbon deposit aspect of fuel cell operation. With both the anode and cathode being the same material the operator can switch between them on desire. As the anode becomes effected by such issues the side that comes under the air and fuel can be switched. This allows for the anode side to be cleaned by the air stream, whereas the clean side that was previously the cathode is now susceptible to the fuel environment of the anode. $^{12}$

A symmetrical fuel cell configuration was used to test the change in polarization resistance in baseline LSM-YSZ cathodes with different types of infiltrates. EIS was performed with a Solatron SI 1260 Impedance/gain-phase analyzer. Measurement parameters were $1 \mathrm{~mA}$ at open circuit voltage measured from $100 \mathrm{~K}$ to $0.05 \mathrm{~Hz}$. Symmetrical cells were prepared by a screen printing procedure. The testing of the cells were carried out using a four point method as shown in Figure 4.1. This method works so that one side of the cell is subject to the measurement parameters where the other side is used as a reference. In this method gold paste was applied in a thin layer over the electrodes of the symmetrical cells. Two silver wire leads were applied at a point on each electrode. The cell was ramped at $2 \mathrm{C} / \mathrm{min}$ to temperatures of 
$600,650,700$, and $750 \mathrm{C}$. Each of these temperatures were held for a period of 24 hours and data points were collected at intervals of every 4 hours. The infiltrates tested consisted of 2.58 wt. \% silver nanoparticles, lanthanum nickelate, and manganese oxide.

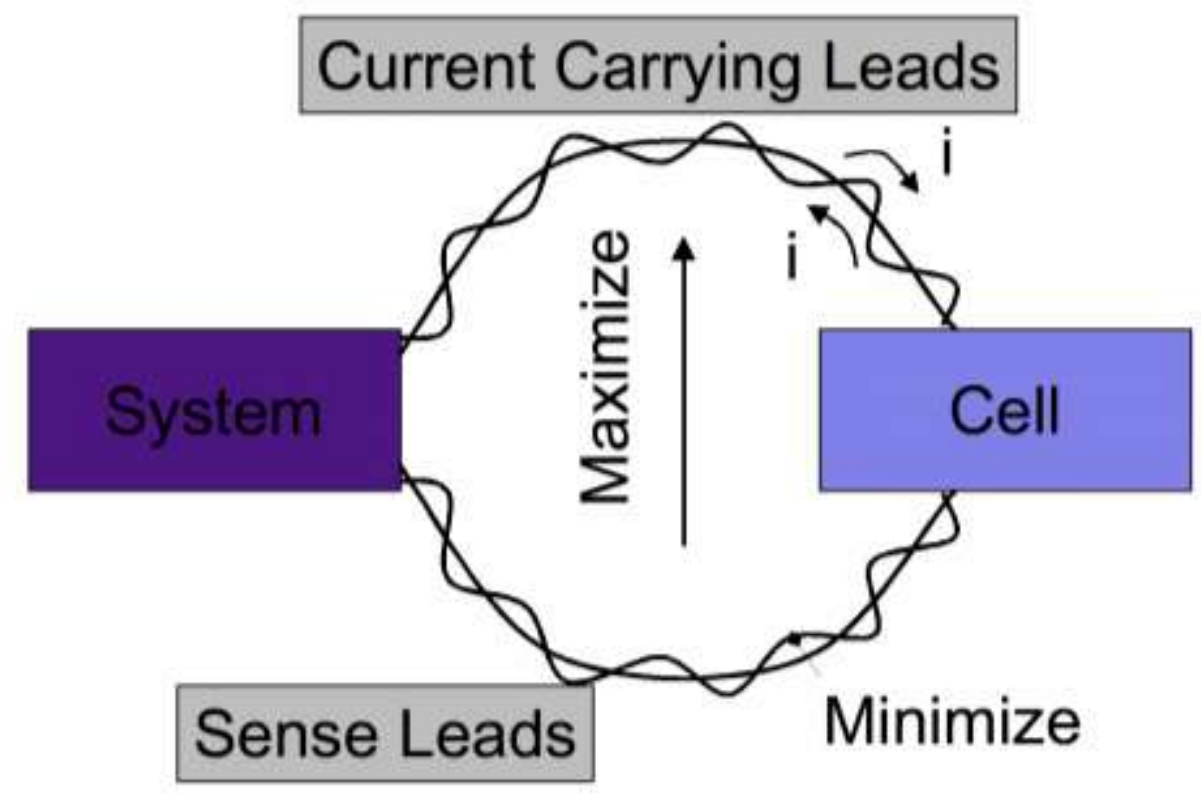

Figure 4.1: Four point measurement schematic ${ }^{13}$

\subsection{Effect of infiltration on LSM/YSZ cathode}

\subsubsection{Infiltration of LSM/YSZ cathode using silver nanoparticles}

In symmetrical fuel cell studies silver $(\mathrm{Ag})$ is one possible candidate that could potentially lower polarization resistance and increase power density. ${ }^{14,15,16}$ Silver can be incorporated as an additive in such systems to promote oxygen surface exchange kinetics. Besides the facts that silver has good catalytic activity and electrical conductivity, it is also of a lower cost than other noble metals that could be used. An advantage to using Ag rather than other noble metals such as $\mathrm{Pd}$ and $\mathrm{Pt}$ is that silver is less reactive for methane oxidation, which is known to result in lower electrical effiency. ${ }^{14}$ 
Silver has been shown to be good at lowering cathode overpotential and raising the power densities of SOFCs in a study by Akhtar. ${ }^{14}$ The modification of cathodes in micro-tubular SOFC systems with Ag for use in a single-chamber environment in order to improve the power densities of such devices was studied. Akhtar's study was carried out in a single chamber with a methane/air mixture. They wanted to improve the cathode of the fuel cell because the cathode overpotential is known to account for most of the power loss in the operation of SOFCs. Akhtar's study focused on the mixed ionic electronic conductor LSCF as the cathode for the fuel cells. In a methane/air mixture of $25 / 60 \mathrm{~mL} \mathrm{~min}^{-1}$ Akhtar's team saw silver to improve the power density of the cells. The maximum power density obtained was $118.4 \mathrm{~mW} \mathrm{~cm}^{-2}$ at $700 \mathrm{C}$. Though the silver had a higher power density it was seen that its performance degraded at an average rate of $5.16 \% / \mathrm{hr}$., whereas the performance of the LSCF-GDC was stable. The reason for the instability was seen in SEM images that showed the degradation to be due to interdiffusion/melting of Ag causing a block in the cathode-electrolyte interface. This was seen to cause interfacial polarization and barrier preventing oxygen ion diffusion through cathodeelectrolyte boundary. This still happened, even though the melting temperature of silver is $960 \mathrm{C}$ and the cell was tested at $700 \mathrm{C}$ due to local heat production in the case of single chamber SOFC operation. Akhtar concluded that silver is in fact a good catalyst for the improving of oxygen adsorption, desorption, dissociation, and diffusion. Though the silver was seen to lower the cathode overpotential and raise the power densities of SOFCs it is not good for single chamber operation due to vaporization, melting, and inter-diffusion at high-temperature operation.

Two separate studies studied the effect of silver on $\mathrm{Ba} 0.5 \mathrm{Sr} 0.5 \mathrm{Co} 0.8 \mathrm{Fe}_{0.2} \mathrm{O}_{3-\delta}$ (BSCF) cathodes. ${ }^{16,17}$ Kedra tested silver electrodes, BSCF electrodes, Ag|BSCF, and Ag|BSCF|Ag composite cathodes. ${ }^{17}$ They saw that silver both reduces ASR in cathodes as well as increasing 
the electrical conductivity. The lowest ASR was seen in the Ag $|\mathrm{BSCF}| \mathrm{Ag}$ cathode. Lin studied silver modified BSCF to be used as a cathode for a proton conducting SOFC. ${ }^{16}$ For EIS measurements a symmetrical cell setup was used. A peak power density of $595 \mathrm{~mW} \mathrm{~cm} \mathrm{~cm}^{-2}$ at 750 $\mathrm{C}$ was seen in contrast to $485 \mathrm{~mW} \mathrm{~cm}^{-2}$ for a BSCF cathode without $\mathrm{Ag}$. $\mathrm{N}_{2} \mathrm{H}_{4}$ was used after silver infiltration the cell was subsequently heated to initiate the reduction of $\mathrm{Ag}^{+}$to $\mathrm{Ag}$. $\mathrm{The}$ tested Ag to BSCF weight percentages at 3.0 and $15 \%$ and named BSCF-3Ag and BSCF-15Ag respectively. They saw the polarization resistance at $650 \mathrm{C}$ in dry air to be $0.55,0.25$, and $0.5 \Omega$ $\mathrm{cm}^{2}$ for BSCF, BSCF-3Ag, and BSCF-15Ag respectively. These are $0.11,0.07$, and $0.10 \Omega \mathrm{cm}^{2}$ at $750 \mathrm{C}$. In protonic fuel cells water is produced at the cathode side rather than the anode side, therefore the effect of water vapor on cell performance had to be studied. In studying the impedance of the BSCF and BSCF-3Ag cells in $3 \% \mathrm{H}_{2} \mathrm{O}$ and dry air at 650 and $600 \mathrm{C}$ it was seen that the polarization resistance of the BSCF-3Ag increased in the wet atmosphere at $650 \mathrm{C}$ whereas the BSCF polarization resistance decreased. At $600 \mathrm{C}$ the $\mathrm{R}_{\mathrm{p}}$ for both the tested cells were seen to increase. The peak power density at $750 \mathrm{C}$ for BSCF-3Ag was seen to be $595 \mathrm{~mW}$ $\mathrm{cm}^{-2}$, whereas that without the silver is $485 \mathrm{~mW} \mathrm{~cm}^{-2}$ at the same conditions. They saw that with excessive silver loading the diffusion process slowed and there were less active sites for ORR.

Wang studied cells prepared with silver - modified LSM cathode powders due to the belief that Ag assists in catalization of the oxygen reduction reaction in the cathode of a SOFC. ${ }^{15}$ Ag nanoparticles were prepared by the reduction of ammoniacal silver nitrate with ascorbic acid in dilute aqueous solutions that contained PVP. When infiltrating a cathode with $1 \mathrm{wt}$ \% Ag they saw the ASR drop from 1.1 to $0.45 \Omega \mathrm{cm}^{2}$ at $750 \mathrm{C}$ in comparison to a pure LSM cathode. In an anode-supported setup they were able to show an increase in the peak power density from 717 to $1199 \mathrm{~mW} \mathrm{~cm}^{-1}$. 
The silver nanoparticles to be infiltrated were in a solution of DI water. The first step was to take a spectrum of the solution to ensure that there was no contamination in it. A standard of gold nanoparticles was taken first and compared to a company website as shown in Figure 4.2. ${ }^{18}$ A UV-Vis spectrum was taken and compared to the literature for silver nanoparticle spectrums. ${ }^{19}$ As can be seen in Figure 4.3 the spectrums did not match.
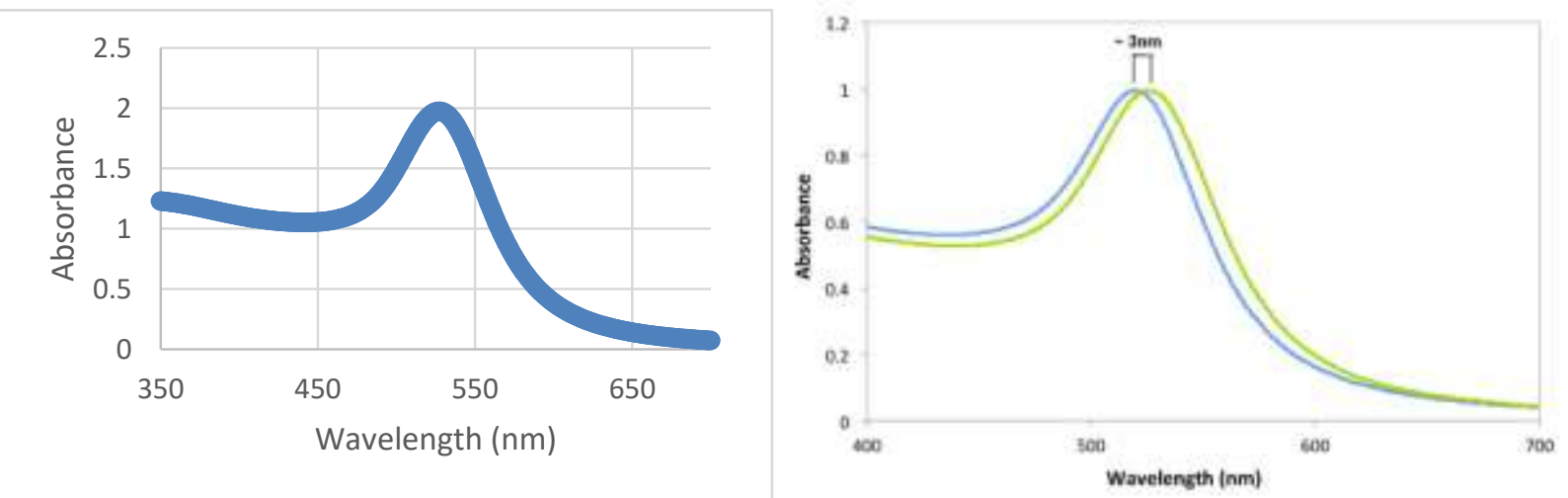

Figure 4.2: UV spectrum of gold nanoparticle standard (left) with reference spectrum of gold nanoparticles (right) ${ }^{18}$
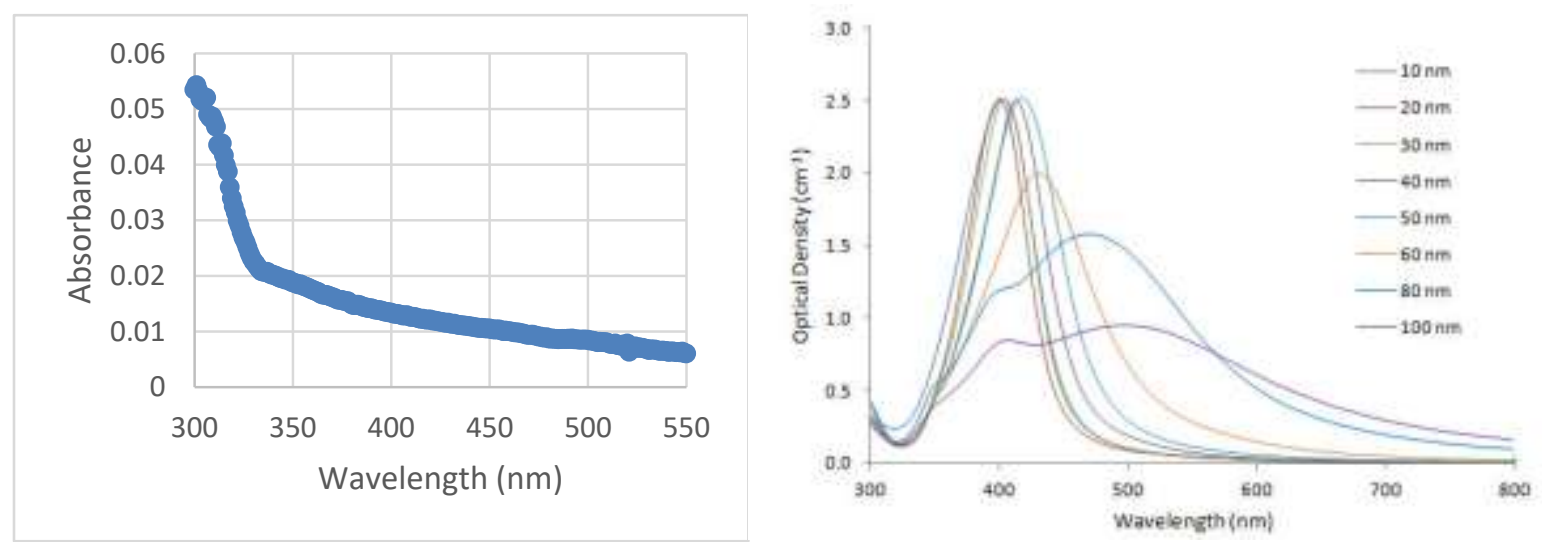

Figure 4.3: Experimental UV silver nanoparticle spectrum compared to reference spectrum $^{19}$

TEM analysis was then performed to study if the present contamination could have an adverse effect on the experiment. Potassium was seen to contaminate the silver nanoparticle solution in images taken with TEM as seen in Figure 4.4. It was decided that potassium would 
not have a significant impact on the performance of the silver infiltration at the small amount present. The solution was therefore accepted to be useable.

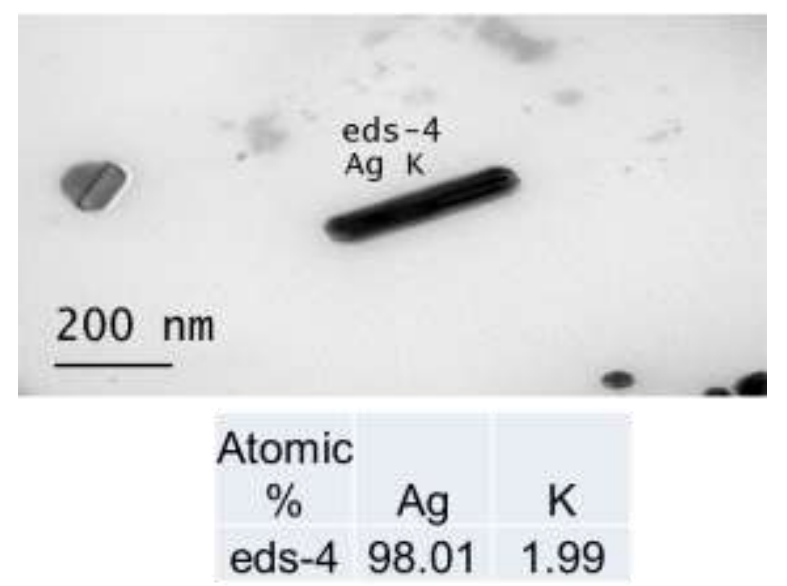

Figure 4.4 TEM confirming presence of a contaminant in Ag-nanoparticle Solution

Infiltration of the silver nanoparticles was carried out by dropping solution onto the surfaces of the cells and allowing them to dry in a furnace at $90 \mathrm{C}$. After the cells dried they were placed in the four point measurement setup for EIS experimentation to be performed.

As can be seen by Figures 4.5, 4.6 and 4.7 the Ag-infiltrates did not seem to effect the fuel cell with respect to the RP, Rs, and RT. The slightly lower polarization resistance of the cells could be due to differences between the base cells rather than due to any particular infiltrate. This shows that silver nanoparticle infiltration of $2.58 \mathrm{wt} . \%$ is not a viable option to be used to better SOFC performance. 

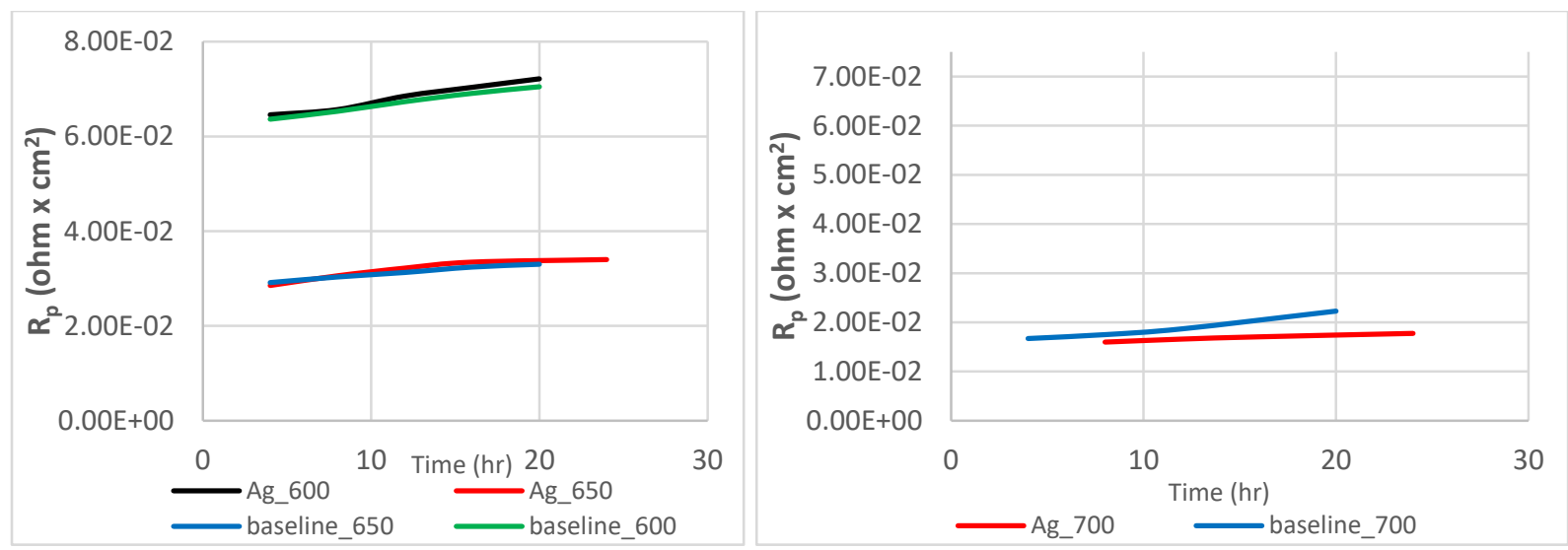

Figure 4.5: Polarization resistance of Ag-nanoparticles compared to baseline ran at 600 and $650 \mathrm{C}$ (left) and $700 \mathrm{C}$ (right)

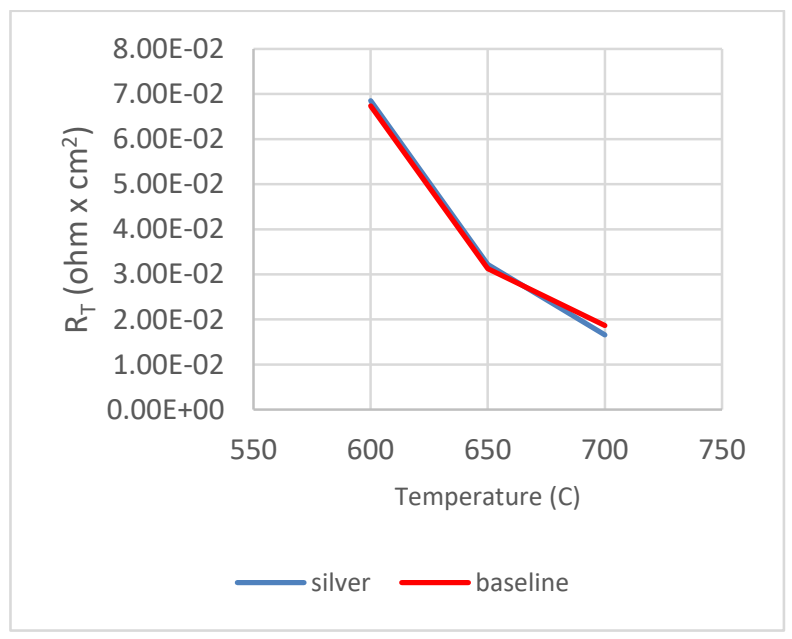

Figure 4.6: Polarization resistance comparison of silver nanoparticle infiltrated LSM/YSZ cell with respect to the baseline LSM/YSZ cell 

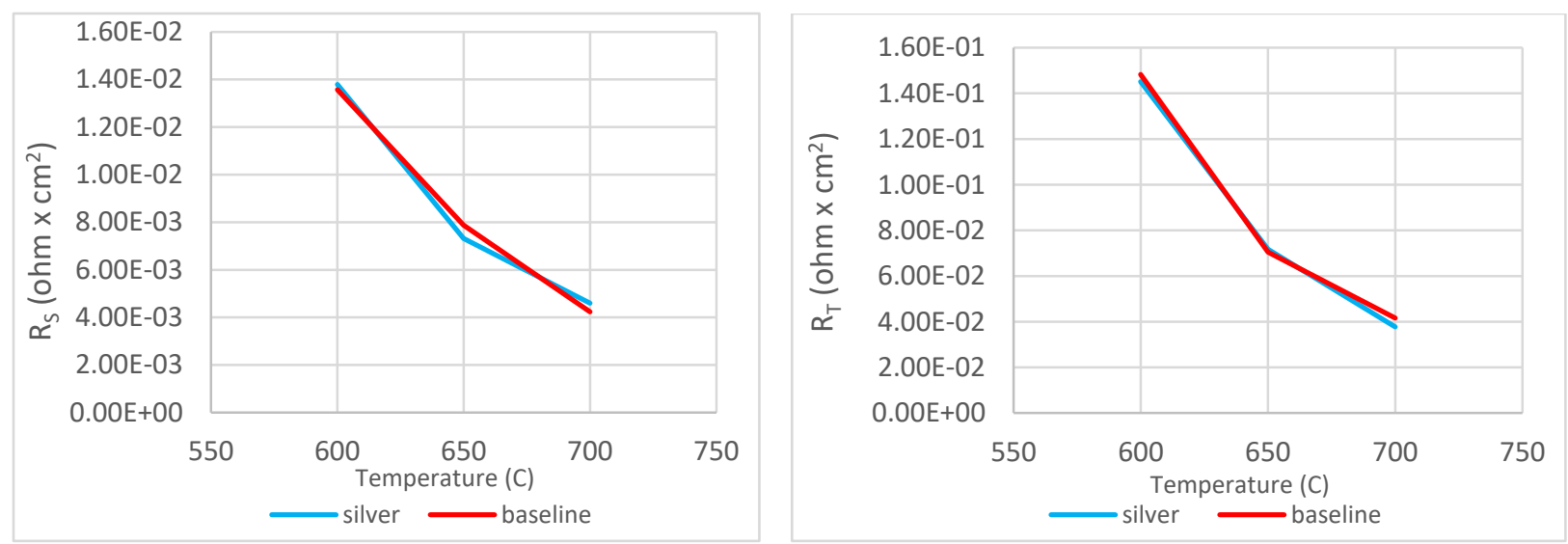

Figure 4.7: Series (left) and total (right) resistance at 12 hours of Ag-nanoparticle infiltrated LSM/YSZ cell with respect to the baseline LSM/YSZ cell

$\underline{\text { Summary of the effect of silver nanoparticle infiltration on the LSM/YSZ cathode }}$

At $2.58 \%$ wt. infiltration silver nanoparticles is seen to offer no improvement to cell resistance. It is believed this may be due to the amount of silver nanoparticles added to the cell being too low to show any improvement. Future studies will focus on higher infiltration weights of silver nanoparticle addition.

\subsubsection{Infiltration of LSM/YSZ cathode using lanthanum nickelates}

Lanthanum nickelates exhibit a Ruddleson-Popper (RP) type of chemistry. This means that their phases can from a formula of $\mathrm{LaNiO}_{3}$ but will decompose at high temperatures into $\mathrm{La}_{2} \mathrm{NiO}_{4}$ and $\mathrm{NiO}$. The higher order nickelates exist in a $\left(\mathrm{A}_{2} \mathrm{BO}_{4+\delta}\right)$ type structure. This specific structure is perovskite layers of $\mathrm{LaNiO}_{4}$ that are separated by rock salt-type layers of $\mathrm{LaO}$.

Materials derived from the perovskite families of $\mathrm{LnFeO}_{3}, \mathrm{LnCoO}_{3}$, and $\mathrm{LnNiO}_{3}$ are studied due to the catalytic activity being determined mainly from the B-site cations. ${ }^{20}$ It is also known that the $\mathrm{Ni}, \mathrm{Co}$, and $\mathrm{Fe}$ based forms exhibit good catalytic activity for ORR. $\mathrm{LaNiO}_{3}$ has been shown to have a good electrical conductivity, however it this can be effected by its 
decomposition to $\mathrm{La}_{2} \mathrm{NiO}_{4}$ and $\mathrm{NiO}$ at high temperatures above $860 \mathrm{C}$ in air. ${ }^{20,21}$ It is difficult to prepare as a single phase in that it requires the use of high-pressure and high-temperature. ${ }^{21}$

The thermal expansion coefficient for lanthanum nickelate is $13.0 \times 10^{-6} \mathrm{~K}^{-1} \cdot{ }^{22}$ Electronic conductivity measurements of the $\mathrm{La}_{2} \mathrm{NiO}_{4} \delta$ show that the material changes from semiconducting to p-type behavior at around $600 \mathrm{~K} .^{22}$

These types of materials have fast oxygen ion diffusion through bulk and rapid surface exchange kinetics. ${ }^{23} \mathrm{La}_{2} \mathrm{NiO}_{4}$ has high oxygen ionic conductivity, good electronic conductivity, moderate thermal expansion coefficients, and high electrocatalytic activity in oxidizing conditions. ${ }^{24}$ The ionic transport in lanthanide nickelates involves the diffusion of the interstitial oxygen ions in the rock salt layers and vacancies in the perovskite planes. ${ }^{25}$ They are good materials due to the availability of unoccupied interstitial sites for oxygen, which gives them a high solubility for oxygen excess. ${ }^{31}$ They have a flexible oxygen stoichiometry causing them to have the ability to hold excess interstitial oxygen under high oxygen partial pressure atmospheres and to have the ability to withstand low $\mathrm{pO}_{2}$ by losing oxygen. ${ }^{23}$ These materials are also an interest in running the fuel cell for electrolysis due to the increase of the $\mathrm{pO}_{2}$ at the oxygen electrode/electrolyte. In conventional materials there is a tendency of membrane failure due to the oxygen pressure increase that is observed at the electrolyte-oxygen electrode interface. The high concentration of oxygen accumulates at the interface, creating a barrier to gas transport which can lead to rupture of the cells. ${ }^{23}$

The disadvantage to the decomposition of this material is not the higher order nickelate phase but rather the $\mathrm{NiO}$. It is known that $\mathrm{NiO}$ is a Mott insulator, therefore it should cause an increase in resistance. ${ }^{26}$ 
In the anode the $\mathrm{LaNiO}_{3}$ phase is undesirable and studies have been done to attempt to prevent it. $^{27}$ It can be a byproduct of a reaction that comes with the diffusion of $\mathrm{La}^{3+}$ ions from the LSGM to a Ni containing anode. This increases the anodic polarization. Oncel believed that this phase interferes with oxygen ion transfer when it forms a thin and continuous layer between the electrolyte and anode.

The reaction that forms this phase in the anode was studied in detail by Zhang. ${ }^{28}$ These were tested by creating pellets of NiO-LSGM, LSGM-SDC, and NiO-SDC and firing the pellets to 1150,1250 , and $1350 \mathrm{C}$ respectively for $2 \mathrm{~h}$ each. After firing the NiO-LSGM pellet it was found that a $\mathrm{LaNiO}_{3}$ compound with a hexagonal structure was present by PXRD patterns. It was shown the amount of this product increased with increase in firing temperature. The $\mathrm{LaNiO}_{3}$ formed in the powder mixture at $1150 \mathrm{C}$. The formation of this phase drastically reduced the conductivity of a cell consisting of LSGM electrolytes and an LSGM-NiO anode that was fired at $1350 \mathrm{C}$.

Lanthanum nickelates could be a good option for introduction into fuel cells on account of their being mixed ionic electronic conductors, whereas LSM is not. ${ }^{29,30}$ There is a possibility MIEC materials can decrease polarization losses by enlarging the electrochemical reaction zone. $^{30}$

This type of material is generally studied to be used at a temperature range between 500 and $700 \mathrm{C}$ to put it at the range of intermediate temperature solid oxide fuel cells. ${ }^{31}$ This electrode would have an advantage over the current LSM/YSZ cathode system as well as the GDC electrolytes with cobaltite cathode systems. The LSM cathode is commonly used as an electrode in high temperature SOFC systems, whereas GDC with a cobaltite, or ferrocobaltite 
cathode is commonly used in intermediate temperature solid oxide fuel cell systems. The problem with LSM is its low catalytic activity at temperatures around $500 \mathrm{C}$, whereas the problem with the cobaltites and ferrocobaltites are their high thermal expansion coefficients compared to the YSZ and CGO electrolytes. ${ }^{29}$

One problem with this class of material is that they are reactive to YSZ and CGO at high temperatures. ${ }^{23,29}$ Montenegro-Hernández found the reactivity between lanthanum nickelates and YSZ to be due to direct reactions between the LNO and YSZ taking place. ${ }^{29}$

Montenegro-Hernández ${ }^{29}$ studied whether reactivity of lanthanum nickelates with electrolytes may be related to the preparation method. Preparation method can change the reactivity due to the effects of preparation on morphology. The team tested $\mathrm{Ln}_{2} \mathrm{NiO}_{4+\delta}$ with three types of synthesis using both CGO and YSZ electrolytes. They used two soft chemical routes of synthesis and a solid state reaction type of synthesis. They used gel for the first method they termed as the Acetate-HMTA method. The second method used citrates for the gel. They used commercial YSZ and CGO fine powders for reactivity tests. After being subjected to heat treatment for 72 hours at $700 \mathrm{C}$ and $900 \mathrm{C}$ in air there were no observed changes in the XRD for the HMTA, CIT, or SSR for lanthanum nickelates. They saw reactions with zirconium and concluded that the reactivity is fastest in lanthanum nickelate-HMTA/YSZ and the corresponding lanthanum nickelate-HMTA/CGO sample.

Laberty argued that one way to potentially increase cathode activity would be to use a single-phase, porous MIEC for the catalysts. ${ }^{32}$ This would cause a two-phase boundary between ions and electrons so the whole surface and not just the TPB would be available for ORR. Laberty believed this $\mathrm{A}_{2} \mathrm{BO}_{4+\delta}$ structure to be stable as well as compatible with YSZ. They 
prepared a composite using a combustion technique. Lanthanum nickelate based cells showed low ohmic resistance of 0.075 thus giving higher power density. Lanthanum nickelates were shown to have poor kinetics for ORR. They showed that although this material doesn't perform well as a single-phase cathode material, it does function well as a composite cathode. They retrieved power densities up to $2.2 \mathrm{~W} \mathrm{~cm}^{-2}$ when using this as a composite bilayer cathode.

Sayers studied whether platinum helped to catalyze the formation of higher order RP phases in the lanthanum nickelate system with a starting chemistry of $\mathrm{La}_{2} \mathrm{NiO}_{4+\delta} .{ }^{31}$ This material is studied as a cathode material between 500 and $700 \mathrm{C}$ to put it at the range of intermediate solid oxide fuel cells. They placed lanthanum nickelate (LNO) powder on a platinum foil substrate for heating, then placed that on a Pt-Rh heating strip. To test the reactivity between LNO and the Pt strip they deposited a thin layer of alumina powder between them. The $\mathrm{La}_{2} \mathrm{NiO}_{4+\delta}$ in contact with platinum oxidizes upon heating forming the higher order Ruddlesden-Popper phases $\mathrm{La}_{3} \mathrm{Ni}_{2} \mathrm{O}_{7-\delta}$ and $\mathrm{La}_{4} \mathrm{Ni}_{3} \mathrm{O}_{10-\delta}$. There were no higher order RP phase when alumina was deposited between the LNO and the Pt strip. This shows that the Pt catalyzes the formation of the higher order RP phases and therefore effects the cathode properties. LNO is believed to be associated with an oxidation process as nickel's oxidation state increases in the order 2-1-4 $<3-2-7<4-3$ 10. Lanthanum deficiency or nickel enrichment was believed to be the cause of the higher order phases. This is due to the lanthanum to Ni cation ratio decreasing with increasing nickel oxidation state. The platinum reduces gaseous oxygen which causes an increase Ni oxidation state causing the formation of the higher order RP phases. The improvement of LNO performance would then be caused by this process's enhancement of the LNO surface exchange processes. 
Sayers also tested the performance of this material as a cathode synthesized by spray pyrolysis in CGO. ${ }^{22}$ The cathode showed high overpotential due to a slow oxygen reaction on its surface. They showed an ASR of $1 \mathrm{ohm} \mathrm{cm}^{2}$ for a cell of LNO with Pt paste and a cell of LNO compact layer and LNO porous layer. They believe that the improved contact at the boundary layer between a thin compact layer of electrode material and the porous electrolyte enhances the oxygen ion transfer to the electrolyte. This causes a reduction in ASR values.

The research conducted in this thesis consisted of infiltration of a targeted $\mathrm{LaNiO}_{3}$ phase into LSM-YSZ symmetrical cells. Yang did a similar experiment using the $\mathrm{La}_{2} \mathrm{NiO}_{4}$ single phase infiltrated into LSGM or SDC cathodes to test as a symmetrical solid oxide fuel cell. ${ }^{24}$ They studied the $\mathrm{La}_{2} \mathrm{NiO}_{4}$ phase of the material due to its properties such as high oxygen ionic conductivity, good electronic conductivity, moderate thermal expansion coefficients, and high electrocatalytic activity in oxidizing conditions. This material is known to convert to a $\mathrm{La}_{2} \mathrm{O}_{3}, \mathrm{Ni}$ mixture after reduction. XRD analysis showed it had a fluorite-type SDC phase and a $\mathrm{K}_{2} \mathrm{NiF}_{4}-$ type $\mathrm{La}_{2} \mathrm{NiO}_{4}$ phase suggesting there was no a reaction between the $\mathrm{La}_{2} \mathrm{NiO}_{4}$ and the SDC. It was shown that the $\mathrm{La}_{2} \mathrm{O}_{3}$ and $\mathrm{Ni}$ phases seem to diffuse onto the exposed SDC scaffold surface during reduction. For the infiltrated into SDC electrodes they did not see concentration polarization at high current density, suggesting a sufficient porosity for free gas diffusion. Both the SDC and LSGM cells reached a power density around $550 \mathrm{~mW} \mathrm{~cm}^{-2}$ at $800 \mathrm{C}$. This was with thick electrolytes with the SDC cells consisting of $\mathrm{La}_{2} \mathrm{NiO}_{4} / \mathrm{SDC}|\mathrm{SDC}(300 \mu \mathrm{m})| \mathrm{La}_{2} \mathrm{NiO}_{4} / \mathrm{SDC}$. It is believed to form a composite in the anode resulting in an extended TPB due to the introduction of oxygen ion conductivity. They showed the infiltrated cell to be much better than a single-phase $\mathrm{La}_{2} \mathrm{NiO}_{4}$ cell. Basically this exists in pure phase in the cathode and in $\mathrm{La}_{2} \mathrm{O}_{3}$ and $\mathrm{Ni}$ composite after reduction in the anode. EIS showed that both $\mathrm{R}_{\mathrm{o}}$ and $\mathrm{R}_{\mathrm{p}}$ is lower in the cell 
with SDC electrolyte than in the cell with LSGM electrolyte even though similar power densities were achieved in both. Relatively stable performance was seen in this cell for 210 hours. The cathode side helped to have a high oxygen reduction activity and the anode side helped with catalytic activity.

The problem with using this material as an anode is that it is known to dissociate into $\mathrm{Ni} / \mathrm{La}_{2} \mathrm{O}_{3}$ upon reduction. Martinelli impregnated $\mathrm{LaNiO}_{3}$ into alumina or zirconia and calcined at $900 \mathrm{C}$ for 4 hours. ${ }^{33}$ They found the complete reduction of $\mathrm{LaNiO}_{3}$ to $\mathrm{La}_{2} \mathrm{O}_{3}$ to occur at around $520 \mathrm{C}$. When there was no support present in the form of either alumina or zirconia there was a rapid deactivation of the catalysts. This rapid deactivation was associated to the deposition of carbon.

Lanthanum nitrate and Nickel nitrate were prepared to create a targeted phase of $\mathrm{LaNiO}_{3}$. Citric acid was used as a chelating agent in a 1:1 molar ratio. ${ }^{34}$ The cell was infiltrated 5 times on each electrode. Between infiltrations the cell was allowed to dry in a vacuum furnace at approximately $90 \mathrm{C}$. The lanthanum nickelate infiltrated cells were heated to $500 \mathrm{C}$ for 30 minutes in order to burn off excess water and any carbon present. The cells were then calcined at $775 \mathrm{C}$ for 5 hours to allow the material to react as well as allowing the nitrogen to burn off. This temperature was used for calcination due to literature showing this substance to decompose at temperatures greater than $860 \mathrm{C}$ in air..$^{20,21}$ The measurement procedure for the lanthanum nickelate infiltrated cells consisted of the use of EIS taken in a four point measurement setup.

XRD was conducted on the powders created from the infiltrate solution to confirm the presence of lanthanum nickelate as shown in Figure 4.8. The XRD analysis shows successful formation of the target $\mathrm{LaNiO}_{3}$ phase. 


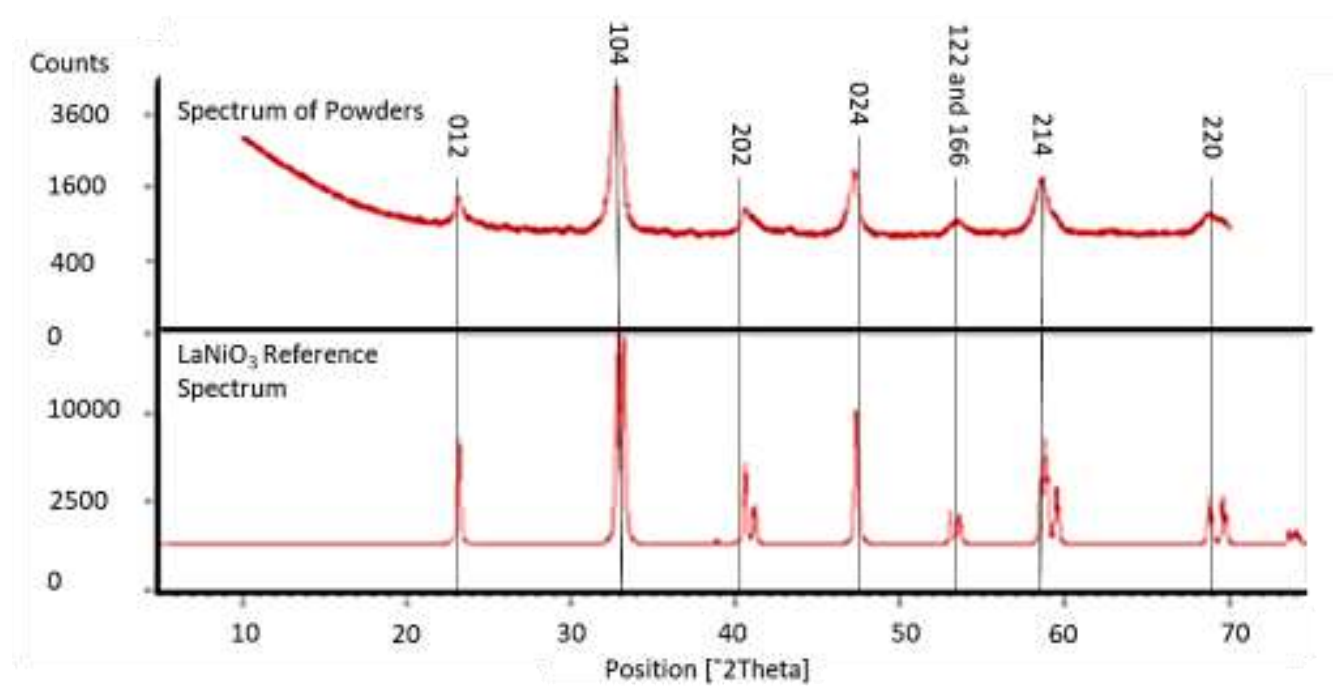

Figure 4.8: XRD of LNNI powders

The LNNI sample is seen to have a lower polarization resistance as temperature increases. When held at each temperature the polarization resistance rises with increasing time for 650,700 , and $750 \mathrm{C}$ but decreases with time at $600 \mathrm{C}$. The decrease in polarization resistance at $600 \mathrm{C}$ is more than likely due to excess ash on the surface after the calcination step. This decrease in polarization resistance would have resulted from the removal of carbon at the lower temperature.

The infiltration of LNNI solution into symmetrical fuel cells greatly reduces the polarization resistance at every temperature with respect to the baseline as is evident in Figure 4.9. At $600 \mathrm{C}$ after being held for 12 hours the polarization resistance of the lanthanum nickelate infiltrated cell is seen to be $75.6 \%$ less than that of the baseline. This makes the material a possible infiltration candidate for intermediate temperature solid oxide fuel cells. This would mean that the infiltrated cells could possibly operate at a temperature lower than with the cathode consisting of only LSM/YSZ. 

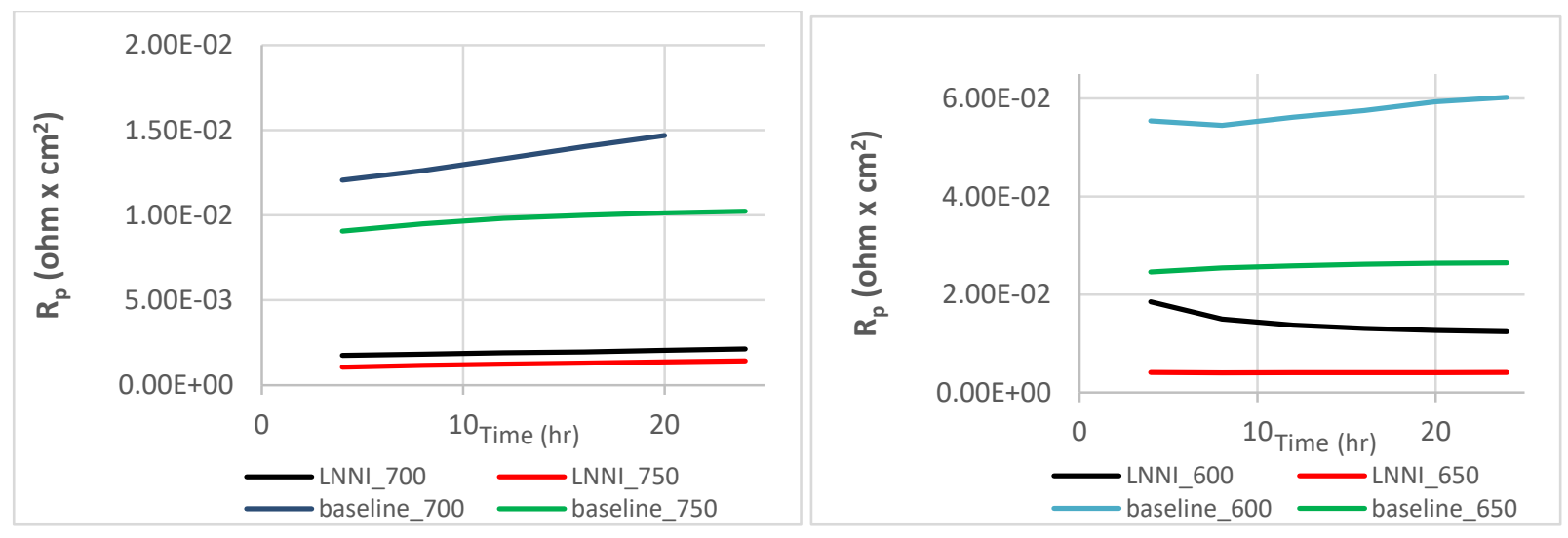

Figure 4.9: Polarization Resistance of Lanthanum Nickelate infiltrated cells in comparison to baseline with temperature ran at 600,650 C (left) and 700, 750 C (right)

It is evident however between Figures 4.10 and 4.11 that the infiltration does not decrease the series resistance as much as it decreases the polarization resistance. The electrical resistivity between the components that make up the series resistance should be decreased as is seen as $\mathrm{LaNiO}_{3}$ is known to be electrically conductive with literature reporting up to $100 \mathrm{~S} \mathrm{~cm}^{-1}{ }^{20}$ It is possible that there is nickel oxide that did not show up in the XRD analysis present in the sample. The removal of all nickel oxide should further decrease the series and total resistance of the samples if it is present.

The series resistance of the lanthanum nickelates also show a convergence to the series resistance of the baseline LSM/YSZ cell as the temperature rises as shown in Figure 4.10. This convergence is also seen in the polarization resistance of the cell in Figure 4.11 but it does not show the infiltrated cell reaching the polarization resistance of the baseline cell at the temperature range measured. The combination of the lower polarization resistance and lower series resistance shows that the lanthanum nickelates aid in both the oxygen reduction reaction and increasing the ionic conductivity. 


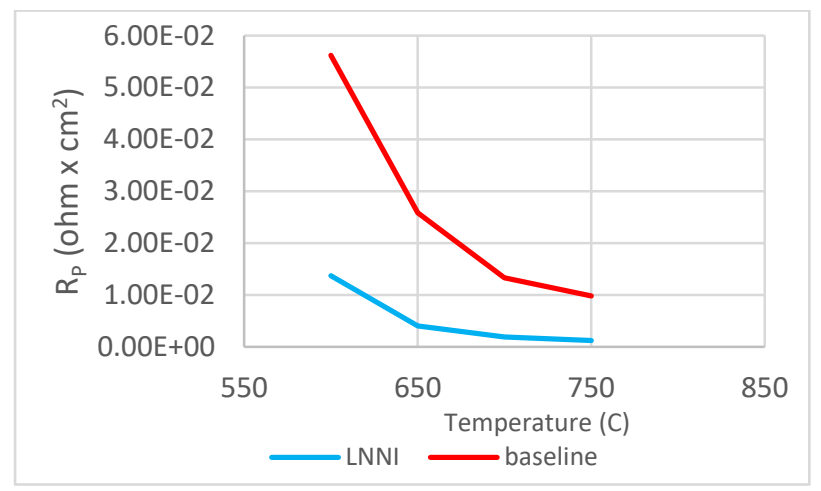

Figure 4.10: Polarization resistance comparison of lanthanum nickelate infiltrated LSM/YSZ cell with respect to the baseline LSM/YSZ cell
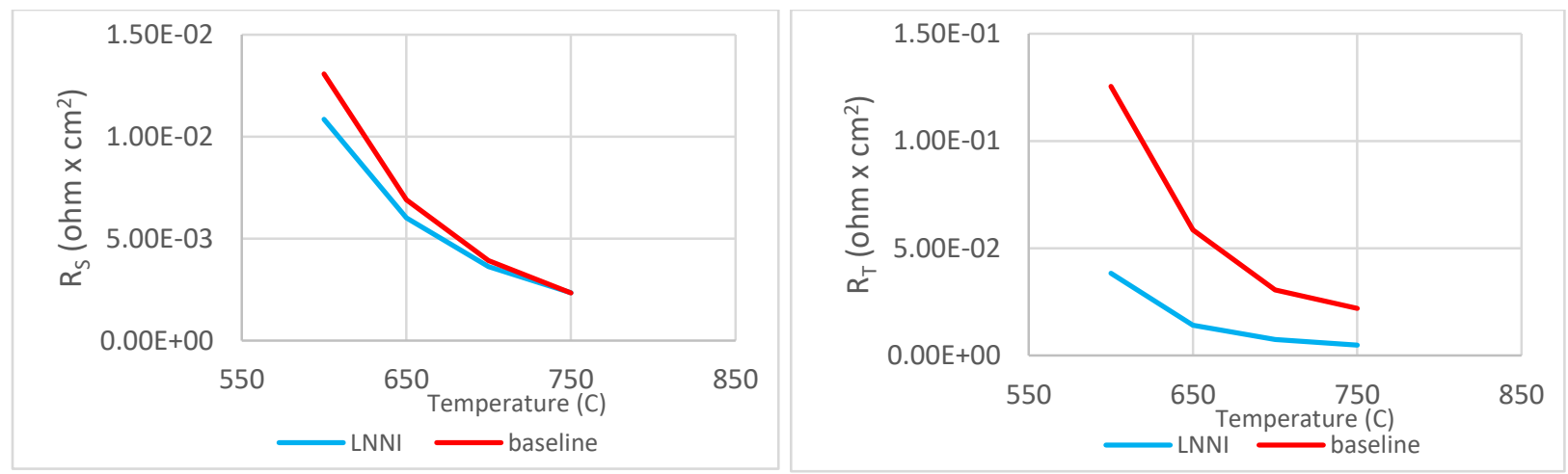

Figure 4.11: Series (left) and total (right) resistance comparison of lanthanum nickelate infiltrated LSM/YSZ cell with respect to the baseline LSM/YSZ cell

Summary of the effect of $\mathrm{LaNiO}_{3}$ infiltration on the LSM/YSZ cathode

The infiltration lanthanum nickelates into the cell has been shown to reduce both polarization resistance and series resistance. The combination of the lower polarization resistance and lower series resistance shows that the lanthanum nickelates aid in both the oxygen reduction reaction and increasing the ionic conductivity. The fact the polarization resistance is 
$75.6 \%$ lower at the 12 hour mark of the lowest temperature studied of $600 \mathrm{C}$ makes this infiltrate an attractive option for further study into IT-SOFC systems.

\subsubsection{Infiltration of LSM/YSZ cathode using manganese oxide}

Manganese oxides exists in the $\mathrm{MnO}, \mathrm{Mn}_{3} \mathrm{O}_{4}, \mathrm{Mn}_{2} \mathrm{O}_{3}$, and $\mathrm{MnO}_{2}$ chemistries of which the lowest resistivity is seen in the $\mathrm{MnO}_{2}$ composition. Manganese exists with oxidation states of $\mathrm{Mn}^{+2}, \mathrm{Mn}^{+3}$, and $\mathrm{Mn}^{+4} .35$

When heated in air $\mathrm{MnO}_{2}$ ore tends to form $\mathrm{Mn}_{2} \mathrm{O}_{3}$ and $\mathrm{Mn}_{3} \mathrm{O}_{4}$ with the $\mathrm{Mn}_{3} \mathrm{O}_{4}$ being formed at the higher temperatures. ${ }^{36}$ Hausmannite $\mathrm{Mn}_{3} \mathrm{O}_{4}$ forms in the spinel structure. ${ }^{37}$ It is both low cost and environmentally friendly. ${ }^{38}$ It does not have a high conductivity with literature putting it between $10^{-7}-10^{-8} \mathrm{~S} \mathrm{~cm}^{-1} .^{38}$ This phase of manganese oxide is a highly stable form relative to the other manganese oxides. ${ }^{37}$ It is commonly used in supercapacitor studies due to its high theoretical specific capacitance of around $1400 \mathrm{Fg}^{-138}$ as well as used as a catalyst for oxidation of methane and $\mathrm{CO} .{ }^{37}$ It is possible that this oxide could decrease the polarization resistance by aiding in the oxygen ion diffusion and oxygen reduction.

Manganese oxide was infiltrated into a symmetrical cell by a chemical vapor deposition method. The measurement procedure for the manganese oxide infiltrated cells consisted of the use of EIS taken in a four point measurement setup.

At $600 \mathrm{C}$ for 12 hours the manganese oxide showed a $72.2 \%$ lower polarization resistance than the baseline at the same parameters as shown in Figure 4.12. Such a large improvement at the lower temperature shows that manganese oxide could be a possible candidate 
to add in order to lower the temperature of solid oxide fuel cell operations. It is seen from the total and series resistance graphs in Figure 4.14 that the resistances start to converge to be more similar to the baseline at higher temperatures. This convergence is also seen in the polarization resistance of the cell in Figure 4.13 but it does not show the infiltrated cell reaching the polarization resistance of the baseline cell at the temperature range measured. Whereas the series resistance becomes approximately the same as the baseline the polarization resistance of the cell is still significantly lower with the manganese oxide at the higher temperature range measured allowing it to be a candidate for full cell studies. The combination of the lower polarization resistance and series resistance shows that the manganese oxide aids in both the oxygen reduction reaction and increasing the ionic conductivity.
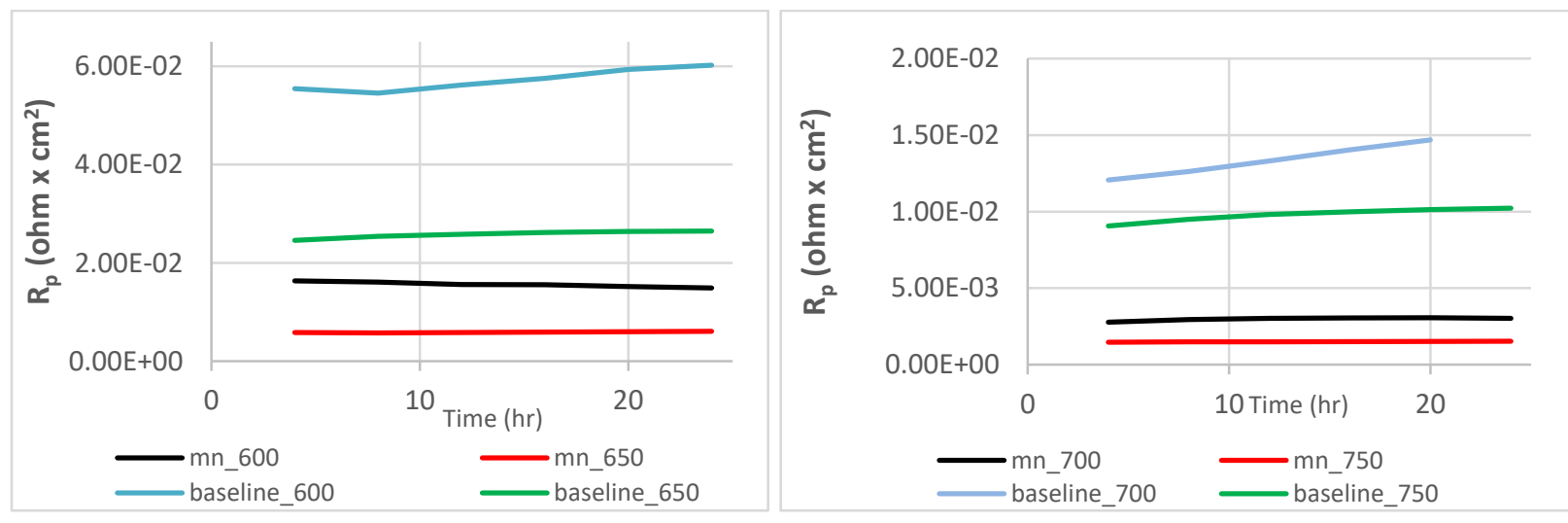

Figure 4.12: Polarization resistance comparison of manganese oxide with respect to the baseline ran at 600, $650 \mathrm{C}$ (left) and 700, $750 \mathrm{C}$ (right) 


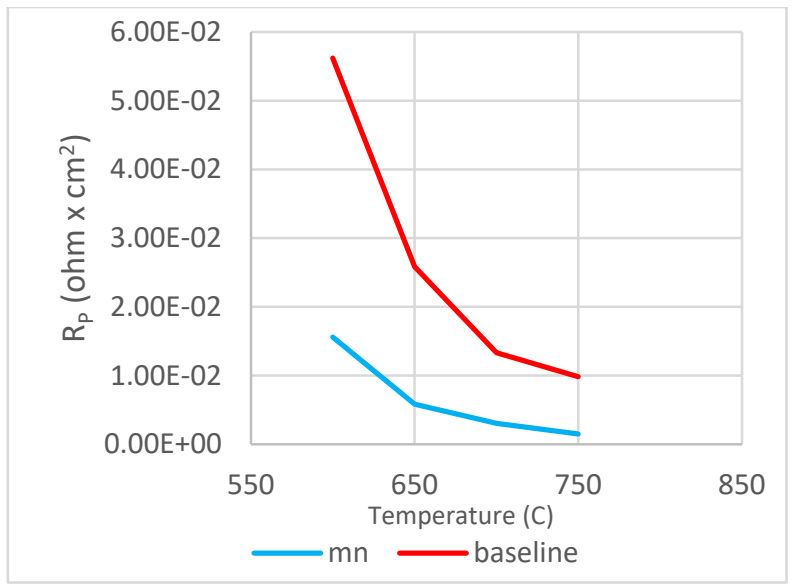

Figure 4.13: Polarization resistance comparison of manganese oxide infiltrated LSM/YSZ cell with respect to the baseline LSM/YSZ cell
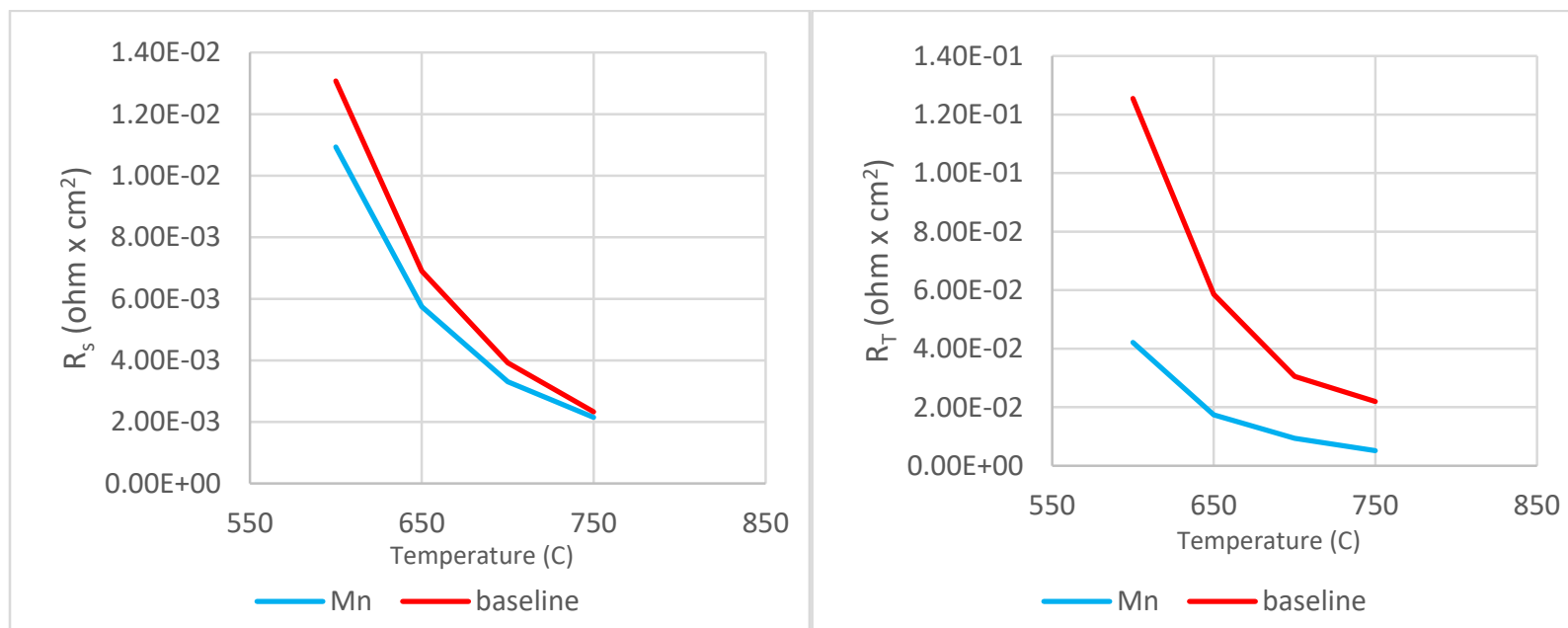

2Figure 4.14: Series (left) and total (right) resistance comparison of manganese oxide infiltrated LSM/YSZ cell with respect to the baseline LSM/YSZ cell

Summary of the effect of manganese oxide infiltration on the LSM/YSZ cathode

The infiltration of manganese oxides into the cell has been shown to reduce both polarization resistance and series resistance. The combination of the lower polarization resistance and lower series resistance shows that the lanthanum nickelates aid in both the oxygen reduction reaction and increasing the ionic conductivity. The fact the polarization resistance is 
$75.6 \%$ lower at the 12 hour mark of the lowest temperature studied of $600 \mathrm{C}$ makes this infiltrate an attractive option for further study into IT-SOFC systems. 


\footnotetext{
${ }^{1}$ In Jiang, S. P., \& In Yan, Y. (2013). Materials for high-temperature fuel cells. Pg 95-98

${ }^{2}$ In Kendall, K., \& In Kendall, M. (2016). High-temperature solid oxide fuel cells for the 21 st century: Fundamentals, design and applications.
}

${ }^{3}$ Torres da Silva, I. M., Nielsen, J., Hjelm, J., \& Mogensen, M. B. (2009). Comparison of the Degradation of the Polarisation Resistance of Symmetrical LSM-YSZ cells, with Anode Supported Ni-YSZ/YSZ/LSM-YSZ SOFCs. E C S Transactions, 25(2), 489-498. DOI: 10.1149/1.320555

${ }^{4}$ Fleig, J. (2003). SOLID oXIDE fUEL cELL cATHODES: Polarization mechanisms and modeling of the electrochemical performance. Annual Review of Materials Research, 33, 361-382.

doi:10.1146/annurev.matsci.33.022802.093258

${ }^{5}$ Singhal, S. C., \& Kendall, K. (2003). High-temperature solid oxide fuel cells: Fundamentals, design, and applicatons. New York: Elsevier Advanced Technology.

${ }^{6}$ Chen, Y., Bunch, J., Jin, C., Yang, C., \& Chen, F. (2012). Performance enhancement of ni-YSZ electrode by impregnation of mo0.1Ce0.9O2 . Journal of Power Sources, 204, 40-45. doi:10.1016/j.jpowsour.2012.01.019

${ }^{7}$ Z., C., W., \& C. (2014). The performance of la0.6Sr1.4MnO4 layered perovskite electrode material for intermediate temperature symmetrical solid oxide fuel cells. Journal of Power Sources, 270, 418-425. doi:10.1016/j.jpowsour.2014.06.163

${ }^{8}$ YANO, S., NAKAMURA, S., HASEGAWA, S., IHARA, M., \& HANAMURA, K. (2009). Solid oxide fuel cell with anodes using proton conductor (Barium-Cerium/Yttrium oxide). Journal of Thermal Science and Technology, 4(3), 431-436. doi:10.1299/jtst.4.431

${ }^{9}$ Nielsen, J., \& Hjelm, J. (2014). Impedance of sOFC electrodes: A review and a comprehensive case study on the impedance of 1SM:YSZ cathodes. Electrochimica Acta, 115, 31-45. doi:10.1016/j.electacta.2013.10.053

${ }^{10}$ Ametek Amt- Princeton Applied Research and Solatron Analytical. Electrochemistry-Electrochemical Impedance Spectroscopy (EIS) Theory. March 17, 2017. Web. Video. June 28, 2018.

https://www.bing.com/videos/search?q=electrochemical+impedance+spectroscopy \&\&view=detail\&mid=45085CF D60771586321F45085CFD60771586321F\&\&FORM=VRDGAR

${ }^{11}$ Hjelm, J. Sogaard, M. Wandel, M. Mogensen, M. Mohan, M. Anke, H. (2007). Electrochemical Impedance Studies of SOFC Cathodes. E C S Transactions, 7(1), 1261-1270. doi:10.1149/1.2729227

${ }^{12}$ Ruiz-Morales, J. C., Canales-Vázquez, J., Peña-Martínez, J., López, D. M., \& Núñez, P. (October 05, 2006). On the simultaneous use of $\mathrm{La} 0.75 \mathrm{Sr} 0.25 \mathrm{Cr} 0.5 \mathrm{Mn} 0.5 \mathrm{O} 3-\delta$ as both anode and cathode material with improved microstructure in solid oxide fuel cells. Electrochimica Acta, 52, 1, 278-284.

${ }^{13}$ EIS Measurement of a Very Low Impedance Lithium Ion Battery. Gamry Instruments. 2018 ... Web. July 23, 2018. https://www.gamry.com/application-notes/EIS/eis-measurement-of-a-very-low-impedance-lithium-ionbattery/

${ }^{14}$ Akhtar, N., \& Kendall, K. (2011). Silver modified cathode for a micro-tubular, single-chamber solid oxide fuel cell. International Journal of Hydrogen Energy, 36(1), 773-778. doi:10.1016/j.ijhydene.2010.10.043 
${ }^{15}$ Wang, Z. Xu, C. Lou, Z. Qiao, J. Ren, B. Sun, K. (2013). Preparation and characterization of silver-modified $\mathrm{La} 0.8 \mathrm{Sr} 0.2 \mathrm{MnO} 3$ cathode powders for solid oxide fuel cells by chemical reduction method. International Journal of Hydrogen Energy, 38(2), 1074-1081.

${ }^{16}$ Lin, Y., Ran, R., \& Shao, Z. (2010). Silver-modified ba $0.5 \mathrm{Sr} 0.5 \mathrm{Co} 0.8 \mathrm{Fe} 0.2 \mathrm{O} 3-\delta$ as cathodes for a proton conducting solid-oxide fuel cell. International Journal of Hydrogen Energy, 35(15), 8281-8288. doi:10.1016/j.ijhydene.2009.12.017

${ }^{17}$ Kedra, A. Mosialek, M. Krzan, M. Tatko, M. Zimowska, M. Bielanska, E. Czerlunczakiewicz, E. Supporting effect of silver on BSCF cathodes for SOFC. Ceramic Materials, 68(1), 70-75. 2016.

${ }^{18}$ Introduction to Gold Nanoparticle Characterization. Cytodiagnostics. Web. March 20, 2018. http://www.cytodiagnostics.com/store/pc/Introduction-to-Gold-Nanoparticle-Characterization-d3.htm

${ }^{19}$ Silver Nanoparticle Properties. Cytodiagnostics. Web. March 20, 2018. http://www.cytodiagnostics.com/store/pc/Silver-Nanoparticle-Properties-d11.htm

${ }^{20}$ Chen, Y., Zhou, W., Ding, D., Liu, M., Ciucci, F., Tade, M., \& Shao, Z. (2015). Advances in cathode materials for solid oxide fuel cells: Complex oxides without alkaline earth metal elements. Advanced Energy Materials, 5(18). ${ }^{21}$ Androulakis, J., Klini, A., Manousaki, A. Growth of polycrystalline LaNi1-xCoxO3 (x $\left.=0.3,0.5\right)$ thin films on Si(100) by pulsed laser deposition. Appl. Phys. A (2004).79(3). 671-675. DOI: 10.1007/s00339-003-2177-6

${ }^{22}$ Sayers, R., Rieu, M., Lenormand, P., Ansart, F., Kilner, J., \& Skinner, S. (2011). Development of lanthanum nickelate as a cathode for use in intermediate temperature solid oxide fuel cells. Solid State Ionics, 192(1), 531-534. doi:10.1016/j.ssi.2010.02.014

${ }^{23}$ Laguna-Bercero, M., Monzón, H., Larrea, A., \& Orera, V. (2016). Improved stability of reversible solid oxide cells with a nickelate-based oxygen electrode. J. Mater. Chem. A, 4(4), 1446-1453. doi:10.1039/C5TA08531D

${ }^{24}$ Y., S., R., T., \& S. (2014). Advanced symmetric solid oxide fuel cell with an infiltrated k 2NiF4-Type la2NiO4 electrode. Energy and Fuels, 28(1), 356-362. doi:10.1021/ef401473w

${ }^{25}$ Kovalevsky, A., Kharton, V., Yaremchenko, A., Pivak, Y., Tsipis, E., Yakovlev, S., . . Frade, J. (2007). Oxygen permeability, stability and electrochemical behavior of Pr2NiO4pd -based materials. Journal of Electroceramics, 18(3-4), 205-218.

${ }^{26}$ Tilley, R. (2013). Understanding solids : The science of materials (2nd ed. ed.). New York: Wiley. pg 848-849

${ }^{27}$ Oncel, C. Ali Gulgun, M. Preventing of $\mathrm{LaNiO}_{3}$ Formation at the LSGM-NiO Interface via LDC Protective Layer and Proper Processing Route for Solid Oxide Fuel Cells. E C S Transactions.(2017). 78(1). 413-427. doi: 10.1149/07801.0413ecst

${ }^{28}$ Zhang, X., Ohara, S., Maric, R., Okawa, H., Fukui, T., Yoshida, H., . . Miura, K. (2000). Interface reactions in the niO-SDC-LSGM system. Solid State Ionics, 133(3), 153-160. doi:10.1016/S0167-2738(00)00744-X

${ }^{29}$ Montenegro-Hernández, A., Vega-Castillo, J., Mogni, L., \& Caneiro, A. (2011). Thermal stability of $\ln 2 \mathrm{NiO} 4 \delta$ (Ln: La, pr, nd) and their chemical compatibility with ySZ and cGO solid electrolytes. International Journal of Hydrogen Energy, 36(24), 15704-15714. doi:10.1016/j.ijhydene.2011.08.105

${ }^{30}$ PEREZCOLl, D., AGUAdERO, A., ESCUdERO, M., NUNEZ, P., \& DAZA, L. (2008). Optimization of the interface polarization of the la2NiO4-based cathode working with the ce1-xSmxO2- $\delta$ electrolyte system. Journal of Power Sources, 178(1), 151-162. doi:10.1016/j.jpowsour.2007.12.030 
${ }^{31}$ Sayers, R., \& Skinner, S. (2010). Evidence for the catalytic oxidation of $\mathrm{La}_{2} \mathrm{NiO}_{4+\delta}$. dOI: 10.1039/c0jm02419h. Journal of Materials Chemistry, 21(2), 414-419. doi:10.1039/c0jm02419h

${ }^{32}$ Labery, C. Zhao, F. Swider-Lyons, K. Virkar, Anil. (2007). High-Performance Solid Oxide Fuel Cell Cathodes with Lanthanum-Nickelate-Based Composites. dOI: 10.1149/1.2760188. Electrochem. Solid-State Lett. 10(10). B170-B174.

${ }^{33}$ Martinelli, D. Melo, D. Garrido Pedrosa, A. Martinelli, A. de F. Melo, M. Batista, M. Bitencourt, R. Use of Perovskite-Type Lanthanum Nickelate Synthesized by the Polymeric Precursor Method in the Steam Reforming Reaction of Methane. Scientific Research An Academic Publisher, 3(6), 363-368. DOI: 10.4236/msa.2012.36052

${ }^{34}$ Babiniec, S., Ricote, S., \& Sullivan, N. (2014). Infiltrated lanthanum nickelate cathodes for use with baCe0.2Zr0.7Y0.1O3 - proton conducting electrolytes. Journal of the Electrochemical Society, 161(6), 723. doi:10.1149/2.037406jes

${ }^{35}$ Nilsen, O., Fjellvåg, H., \& Kjekshus, A. (2003). Growth of manganese oxide thin films by atomic layer deposition. Thin Solid Films, 444(1), 44-51. doi:10.1016/S0040-6090(03)01101-5

${ }^{36}$ Serensen, B. Gaal, S. Tangstad, M. Ringdalen, E. Kononov, R. Ostrovski, O. Properties of Manganese Ores and Their Change in the Process of Calcination. The Twelfth International Ferroalloys Congress Sustainable Future. Ferromanganese-Pretreatment for Smelting. June 6-9, 2010. 439-448.

${ }^{37}$ Dubal, D., Dhawale, D., Salunkhe, R., Pawar, S., \& Lokhande, C. (2010). A novel chemical synthesis and characterization of mn3O4 thin films for supercapacitor application. Applied Surface Science, 256(14), 4411-4416. doi:10.1016/j.apsusc.2009.12.057

${ }^{38}$ Z., A., D., \& S. (2016). A facile and template-Free one-Pot synthesis of mn3O4 nanostructures as electrochemical supercapacitors. Nano-Micro Letters, 8(2), 165-173. doi:10.1007/s40820-015-0074-0 


\section{Chapter 5: Conclusions and planned work for the future}

It has been shown that barium oxide is a potential infiltrate for the anode of solid oxide fuel cells. An optimal chemistry was found in BaO-5. This sample consisted of $3 \mathrm{~g}$ barium nitrate/ $100 \mathrm{~mL} \mathrm{H}_{2} \mathrm{O}, 800 \mathrm{C}$ calcination for two hours, and 1:1 mole ratio citric acid to barium nitrate. The effectiveness of the infiltration in this cell has been confirmed with SEM, EDS, and TEM analysis.

For future work, a cell should be ran and analyzed under an $\mathrm{H}_{2}$ environment for improvements in power density. Analysis should be done to see if reactions happened that could possibly open up proton conducting pathways. If improvement is seen in an $\mathrm{H}_{2}$ environment the cell should be further studied in both environments containing sulfur and environments with $\mathrm{CH}_{4}$ as the fuel source. The environments containing sulfur and the environments containing $\mathrm{CH}_{4}$ will confirm this infiltrate's ability to mitigate sulfur poisoning and carbon deposition respectively.

It has been shown that resistances associated with the cathode of a solid oxide fuel cell can be reduced through modification using infiltration techniques. Though a $2.58 \mathrm{wt} . \%$ of silver nanoparticle infiltration showed no improvement in the cell from a resistance standpoint, infiltration of $\mathrm{LaNiO}_{3}$ and ALD deposition of manganese oxide both resulted in improved resistance.

Future work should be done to look for possible improvements in silver nanoparticle infiltration at a higher weight percent of infiltration into the cells. It is possible that silver nanoparticle infiltration could improve the resistance but that the $2.58 \%$ used in this work was not enough to see the effects. 
Lanthanum nickelate chemistry needs further tested to ensure no nickel oxide particles are present in the sample. Though XRD does not show a nickel oxide phase it is possible some is present. The presence of the insulating nickel oxide could increase the series and total resistance of the cell adversely effecting cell performance. The chemistry and infiltration parameters need optimized to ensure this does not happen.

Modifications should be done to the chemistries of the lanthanum nickelate and the manganese oxide to further improve their resistances. These would include dopants into the structures as well as researching higher ordered phases of the lanthanum nickelates. Other members of the nickelate family such as Pr-nickelates and Nd-nickelates should also be studied for lowering the resistances.

The infiltration lanthanum nickelates into the cell has been shown to reduce both polarization resistance and series resistance. The combination of the lower polarization resistance and lower series resistance shows that the lanthanum nickelates aid in both the oxygen reduction reaction and increasing the ionic conductivity. The fact the polarization resistance is $75.6 \%$ lower at the 12 hour mark of the lowest temperature studied of $600 \mathrm{C}$ makes this infiltrate an attractive option for further study into IT-SOFC systems.

In the future the material should be further optimized to ensure no nickel oxide is present in the material. Though the XRD did not show any nickel oxide present further characterization should be done to ensure this. Once the materials are optimized with respect to resistances a full cell should be studied in operation with the cathodes infiltrated with the material. Future studies will also plan for studying the higher order Ruddleson Popper phases of this material as infiltrates such as the $\mathrm{La}_{2} \mathrm{NiO}_{4}$ phase to compare to the current results. 
The infiltration of manganese oxides into the cell has been shown to reduce both polarization resistance and series resistance. The combination of the lower polarization resistance and lower series resistance shows that the lanthanum nickelates aid in both the oxygen reduction reaction and increasing the ionic conductivity. The fact the polarization resistance is $75.6 \%$ lower at the 12 hour mark of the lowest temperature studied of $600 \mathrm{C}$ makes this infiltrate an attractive option for further study into IT-SOFC systems.

Future work on the manganese oxide will include testing the oxides for a multiple numbers of cycles deposited. This will be the same as adding or subtracting thicknesses of the deposition layers. The manganese oxides will also be tried as an infiltrate and evaluated to understand if this method yields different results than the ALD deposition. Last, different chemistries may be tested that involve the use of dopants into the manganese oxides. 